\title{
Primary marine aerosol emissions from the Mediterranean Sea during pre-bloom and oligotrophic conditions: correlations to seawater chlorophyll $\boldsymbol{a}$ from a mesocosm study
}

\author{
A. N. Schwier ${ }^{1}$, C. Rose $^{1}$, E. Asmi ${ }^{1, a}$, A. M. Ebling ${ }^{2}$, W. M. Landing ${ }^{2}$, S. Marro ${ }^{3,4}$, M.-L. Pedrotti ${ }^{3,4}$, A. Sallon ${ }^{3,4}$,

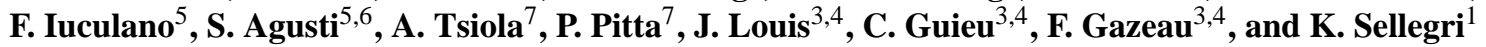 \\ ${ }^{1}$ Laboratoire de Météorologie Physique CNRS UMR6016, Observatoire de Physique du Globe de Clermont-Ferrand, \\ Université Blaise Pascal, 63171 Aubière, France \\ ${ }^{2}$ Department of Earth, Ocean, and Atmospheric Science, Florida State University, Tallahassee, FL 32306-4520, USA \\ ${ }^{3}$ Laboratoire d'Océanographie de Villefranche (LOV), CNRS UMR7093, Observatoire océanologique, \\ 06230 Villefranche-sur-mer, France \\ ${ }^{4}$ Sorbonne Universités, UPMC Univ Paris 06, UMR7093, LOV, Observatoire océanologique, 06230 Villefranche-sur-mer, \\ France \\ ${ }^{5}$ Instituto Mediterráneo de Estudios Avanzados (IMEDEA CSIC-UIB), 07190 Esporles, Mallorca, Spain \\ ${ }^{6}$ The UWA Oceans Institute and School of Plant Biology, University of Western Australia, 35 Stirling Highway, \\ Crawley 6009, Australia \\ ${ }^{7}$ Hellenic Centre for Marine Research (HCMR), P.O. Box 2214, 71003 Heraklion, Crete, Greece \\ ${ }^{a}$ now at: Finnish Meteorological Institute, P.O. Box 503, 00101, Helsinki, Finland
}

Correspondence to: K. Sellegri (k.sellegri@opgc.univ-bpclermont.fr)

Received: 24 July 2014 - Published in Atmos. Chem. Phys. Discuss.: 20 October 2014

Revised: 2 April 2015 - Accepted: 8 June 2015 - Published: 20 July 2015

\begin{abstract}
The effect of ocean acidification and changing water conditions on primary (and secondary) marine aerosol emissions is not well understood on a regional or a global scale. To investigate this effect as well as the indirect effect on aerosol that changing biogeochemical parameters can have, $\sim 52 \mathrm{~m}^{3}$ pelagic mesocosms were deployed for several weeks in the Mediterranean Sea during both winter pre-bloom and summer oligotrophic conditions and were subjected to various levels of $\mathrm{CO}_{2}$ to simulate the conditions foreseen in this region for the coming decades. After seawater sampling, primary bubble-bursting aerosol experiments were performed using a plunging water jet system to test both chemical and physical aerosol parameters (10-400 nm). Comparing results obtained during pre-bloom and oligotrophic conditions, we find the same four lognormal modal diameters $(18.5 \pm 0.6,37.5 \pm 1.4,91.5 \pm 2.0$, $260 \pm 3.2 \mathrm{~nm}$ ) describing the aerosol size distribution during both campaigns, yet pre-bloom conditions significantly increased the number fraction of the second (Aitken) mode,
\end{abstract}

with an amplitude correlated to virus-like particles, heterotrophic prokaryotes, TEPs (transparent exopolymeric particles), chlorophyll $a$ and other pigments. Organic fractions determined from kappa closure calculations for the diameter, $D_{\mathrm{p}} \sim 50 \mathrm{~nm}$, were much larger during the pre-bloom period (64\%) than during the oligotrophic period (38\%), and the organic fraction decreased as the particle size increased. Combining data from both campaigns together, strong positive correlations were found between the organic fraction of the aerosol and chlorophyll $a$ concentrations, heterotrophic and autotrophic bacteria abundance, and dissolved organic carbon (DOC) concentrations. As a consequence of the changes in the organic fraction and the size distributions between pre-bloom and oligotrophic periods, we find that the ratio of cloud condensation nuclei $(\mathrm{CCN})$ to condensation nuclei (CN) slightly decreased during the pre-bloom period. The enrichment of the seawater samples with microlayer samples did not have any effect on the size distribution, organic content or the $\mathrm{CCN}$ activity of the generated primary aerosol. 
Partial pressure of $\mathrm{CO}_{2}, p \mathrm{CO}_{2}$, perturbations had little effect on the physical or chemical parameters of the aerosol emissions, with larger effects observed due to the differences between a pre-bloom and oligotrophic environment.

\section{Introduction}

With oceans covering $71 \%$ of the Earth's surface, sea spray aerosol comprises a large portion of the natural aerosol emissions, with an estimated contribution between 2000 and $10000 \mathrm{Tg} \mathrm{yr}^{-1}$ for aerosols with diameter $D_{\mathrm{p}}<20 \mu \mathrm{m}$ (Gantt and Meskhidze, 2013). Marine aerosol can be produced from primary processes (e.g. sea spray aerosol from breaking waves) and secondary processes (i.e. formation via chemical processing or gas-to-particle conversion). These aerosols can then have a large impact upon the Earth's radiative budget through both direct effects, such as light scattering, and indirect effects, by becoming cloud condensation nuclei (CCN) and affecting cloud formation and cloud properties (Novakov and Corrigan, 1996; Novakov and Penner, 1993). Due to the large flux of marine aerosol into the atmosphere, it is critical to better understand and determine the physical and chemical properties of marine aerosol as a function of changing marine environment water conditions.

At wind speeds greater than $4 \mathrm{~ms}^{-1}$, primary marine aerosol is primarily formed via bubble bursting from breaking waves; three main types of drops, film, spume and jet drops, are produced depending on the mechanism (Lewis and Schwartz, 2004). Based on the size of aerosol formed, the chemical composition ranges from primarily inorganic sea spray particles to particles rich in organic material, yet different studies have shown differing compositions over the same size range. Typically, particles of diameter $D_{\mathrm{p}}>1 \mu \mathrm{m}$ have been found to be largely sea salt, whereas smaller particles $D_{\mathrm{p}}<1 \mu \mathrm{m}$ contain increasing concentrations of organics with decreasing diameter (Ault et al., 2013; Facchini et al., 2008; Keene et al., 2007; O'Dowd et al., 2004; Prather et al., 2013). For particles in the size range relevant to cloud formation (50-150 nm), some have found an absence of hygroscopic salts in particles below $200 \mathrm{~nm}$ (Bigg and Leck, 2008), while other studies have shown the presence of sea salt and other inorganic elements (Ault et al., 2013; Clarke et al., 2006; Murphy et al., 1998; Quinn and Bates, 2011). Marine organic species remain largely uncharacterized (Benner, 2002), and organic concentrations can vary drastically throughout the water column, both temporally and spatially (Russell et al., 2010). Primary emissions can gain organics either as bubbles traverse through the water column or at the ocean surface from the organic rich microlayer (Barger and Garrett, 1970; Bigg and Leck, 2008; Blanchard, 1964; Blanchard and Woodcock, 1957; Garrett, 1967; Lion and Leckie, 1981; Matrai et al., 2008). The sea surface microlayer has been shown to exhibit physical, chemical and bio- logical differences from oceanic subsurface water (Cunliffe et al., 2013).

The primary marine aerosol emission flux is characterized by different source functions, the number of aerosols by particle size by area by time (Lewis and Schwartz, 2004). These source functions are dependent on a number of physical parameters, dominated by wind speed and sea surface temperature, but are also affected by the sea state (wave height, shape, etc.) and salinity (Grythe et al., 2014). Aerosol emissions are also dependent on the chemical composition of the seawater due to the presence of a rich and varied mixture of organic material. These organics can affect the waters' ability to form whitecaps (Callaghan et al., 2012) and change bubble lifetime (Garrett, 1967). Large-scale marine aerosol source functions used in models have started to include seawater composition (Langmann et al., 2008; Spracklen et al., 2008; Vignati et al., 2010) by focusing on parameterizations of the correlation between surface water chlorophyll $a$ (chla) concentrations and aerosol organic fractions (O'Dowd et al., 2008; Rinaldi et al., 2013).

Previous studies have indicated changing size distribution with increasing organic material (Fuentes et al., 2010b; King et al., 2012; Sellegri et al., 2006). Sellegri et al. (2006) saw a log-normal mode amplitude shift towards smaller diameters with the addition of sodium dodecyl sulfate (SDS) to artificial seawater; Fuentes et al. (2010b) observed similar behavior in tests with artificial seawater and biogenic exudates, while King et al. (2012) saw an additional lognormal mode at $200 \mathrm{~nm}$ with the addition of organic material to artificial seawater. Water temperature has also shown an effect on aerosol size distribution and number concentration, though different groups have seen varying trends. Mårtensson et al. (2003) saw increasing number concentrations for particles $>350 \mathrm{~nm}$ and decreasing concentrations for particles $<70 \mathrm{~nm}$ with increasing water temperature in measurements of synthetic seawater. For all diameters in between, there was no clear trend. Sellegri et al. (2006) compared artificial seawater at 4 and $23{ }^{\circ} \mathrm{C}$ and found that the lognormal modal diameters all decreased with decreasing water temperature. Zábori et al. (2012b) measured the size distribution of $\mathrm{NaCl}$ and succinic acid/ $\mathrm{NaCl}$ aerosol produced from an impinging water jet over a temperature range from 0 to $16^{\circ} \mathrm{C}$ and found that the temperature did not influence the size distribution, yet it did influence the magnitude of aerosols produced (increasing temperatures led to decreased aerosol production). The dominance of small particles (dry diameter $10-250 \mathrm{~nm}$ ) decreased with increasing water temperature over the range $0-10^{\circ} \mathrm{C}$. Above $10^{\circ} \mathrm{C}$, total number concentrations were stable regardless of the temperature. Similar results were found testing winter Arctic Ocean water (Zábori et al., 2012a) and Baltic seawater (Hultin et al., 2011), though for the Baltic seawater, the number concentration continued to drop until a water temperature of $\sim 14^{\circ} \mathrm{C}$.

Concentrations of marine organic aerosol seem to be highly dependent on the biological productivity at the ocean 
surface, following a seasonal bloom cycle. Studies performed at Mace Head in the North Atlantic Ocean and Amsterdam Island in the southern Indian Ocean determined that the organic concentrations as well as the organic: sea salt ratios were highest in the spring/summer and the lowest in the winter (Sciare et al., 2000, 2009; Yoon et al., 2007). Phytoplankton blooms lead to increased levels of organic material (OM), both dissolved and particulate (Ducklow et al., 1995), with dissolved organic carbon (DOC) concentrations often greater than $80 \mu \mathrm{M}$ under bloom conditions (Hansell et al., 2009). Different studies have linked the total submicron organic mass fraction of sea spray aerosol to chla levels observed by satellite (Albert et al., 2012; O'Dowd et al., 2008; Rinaldi et al., 2013; Vignati et al., 2010); other studies have shown that the organic mass fraction was correlated with dimethylsulfide (DMS) (Bates et al., 2012) or heterotrophic bacteria abundance (Prather et al., 2013) instead. Hultin et al. (2010) measured seawater at depths of $2 \mathrm{~m}$ during an ocean cruise west of Ireland and did not observe a correlation between chla and sea spray production, instead finding a relationship with dissolved oxygen. Rinaldi et al. (2013) found that the correlation between chla and OM at Mace Head was higher than the correlation of colored dissolved organic material or seawater particulate organic carbon; however, the optimum correlation between chla and OM was observed with an 8-day time lag for chla, indicating a complex, indirect relationship between biological processes and transferable organic matter. Various studies have shown linear correlations between chla concentrations and organic fraction (O'Dowd et al., 2008; Rinaldi et al., 2013); others have observed an exponential fitting correlation (Gantt et al., 2011), a power fit correlation (Fuentes et al., 2011), or a Langmuir functional relationship correlation (Long et al., 2011).

The CCN activity of marine aerosol has been tested in various laboratory experiments. Fuentes et al. (2010a) determined a plunging water jet system to be the bubble generation method most representative of ambient marine aerosol. In a separate study, Fuentes et al. (2010b) collected seawater samples from the west African coast for CCN measurements with phytoplankton exudates and saw a shift towards higher number concentrations and smaller diameters in samples with high biological material. They found a variable relationship between chla concentrations and OM production, stating that organic enrichment might also be dependent on specific conditions of algal blooms. The same data set showed an increase in critical supersaturation of 5-24\% for the samples with high biological material compared to artificial seawater (Fuentes et al., 2011). Moore et al. (2011) performed laboratory experiments with $\mathrm{NaCl}$ or artificial seawater in combination with SDS, Synechococcus, Ostreococcus or oleic acid and found that $100 \times$ the normal organic concentration still did not affect the CCN activity or cloud formation properties. King et al. (2012) tested artificial seawater with different organics (palmitic acid, sodium laurate, fructose, mannose, SDS) and found that the number concentra- tion decreased with the presence of stronger surfactants, most likely due to surface layer stabilization. The CCN activity was dependent on the contribution of the varying salts in the particle phase rather than the organics. In recent wave channel experiments with natural seawater, Prather et al. (2013) saw the activation diameter augment from 63 to $118 \mathrm{~nm}$ after a 5-fold increase in bacteria abundance; the size distributions remained essentially unchanged (as did phytoplankton, chla and total organic carbon (TOC) abundances and concentrations), leading to the notion that a change in the sea spray chemical composition (the number fraction mode) must have affected the activation diameter. During the same campaign, Collins et al. (2013) observed the hygroscopicity parameter kappa, $\kappa$, reduce by $86 \pm 5 \%$ over the same time period as the bacterial increase.

The production of organic matter in oceanic surface water is expected to be substantially modified in the coming decades as a consequence of climate change and ocean acidification (Doney et al., 2012). Ocean acidification is defined as the increase in ocean acidity and associated changes in seawater chemistry, due to the absorbance of a very significant amount of anthropogenic $\mathrm{CO}_{2}$ by the oceans $(2.5 \pm 0.5 \mathrm{GtC}$ or $\sim 26.3 \%$ of anthropogenic emissions, Le Quéré et al., 2015). Since the beginning of the industrial era, the $\mathrm{pH}$ in ocean surface waters has already decreased by 0.1 units, on average, equivalent to an increased acidity of $26 \%$. Further acidification is expected by 2100 , ranging from 0.06 to 0.32 units, equivalent to an increased acidity of $15-110 \%$, depending on the considered $\mathrm{CO}_{2}$ emission scenario (Ciais et al., 2013). Although it is well established that ocean acidification has the potential to significantly impact marine biological processes (see Riebesell and Tortell, 2011 and Weinbauer et al., 2011 for a comprehensive review), it is still unclear how these changing biogeochemical water conditions will affect the properties and production of marine aerosols. Furthermore, the effect of such an acidification and consequently the resulting feedback on Mediterranean marine aerosol and the regional climate remains unknown.

Mesocosms are defined as experimental enclosures from one to several thousands of liters that maintain natural communities under close-to-natural conditions (Riebesell et al., 2013). They have been increasingly used in both aquatic and terrestrial ecology (Stewart et al., 2013), especially on the effects of environmental and/or anthropogenic disturbances on a large variety of chemical and biological processes. In the context of ocean acidification, mesocosms have been used on several occasions for experimental time periods spanning from a few days to a few weeks, and were found to be efficient in studying the effects of this driver over such short time scales (Riebesell et al., 2008, 2013). Archer et al. (2013) recently showed, during a mesocosm experiment in the Arctic, that with seawater acidification and increased $\mathrm{CO}_{2}$ concentrations, average concentrations of DMS decreased by up to $60 \%$ at the lowest $\mathrm{pH}$. Inversely, 
concentrations of dimethylsulfoniopropionate (DMSP), the precursor to DMS, increased by up to $50 \%$. In the remote ocean, DMS was predicted by modeling studies to be one of the main precursors for $\mathrm{CCN}$ in the marine boundary layer, and studies have shown that regional DMS emission changes could affect CCN sensitivity (Cameron-Smith et al., 2011; Woodhouse et al., 2013).

Many past mesocosm experiments which focused on the effects of ocean acidification have been performed in relatively eutrophic conditions or with nutrient addition initially or during the experiment. However, about $60 \%$ of the ocean surface is associated with low productivity, termed oligotrophic areas. Decreased nutrient availability and the expansion of low-productivity regions are projected with increasing $\mathrm{CO}_{2}$ concentrations, as enhanced thermal stratification is expected to lead to surface layer nutrient depletion (Irwin and Oliver, 2009; Polovina et al., 2008). Nutrient availability also might have strong effects on the community response to ocean acidification (Hare et al., 2007), so there is a clear need to evaluate the sensitivity of oligotrophic marine environments to this anthropogenic effect. The Mediterranean Sea is one of the most nutrient-poor waters in the world with maximum open sea area chlorophyll concentrations of $2-3 \mathrm{mg} \mathrm{m}^{-3}$. Its trophic status varies from oligotrophic-mesotrophic in the northwestern basin to extremely oligotrophic in the eastern basin (Moutin and Raimbault, 2002; The MerMex Group, 2011). High biological activity occurs annually in parts of the western Mediterranean, including coastal France in the late winter and early spring (D'Ortenzio and Ribera d'Alcalà, 2009; Siokou-Frangou et al., 2010).

In this work, we collected water from three mesocosms deployed in the Northwestern Mediterranean Sea over two campaigns during different seasons as part of the European Mediterranean Sea Acidification in a changing climate (MedSeA; http://medsea-project.eu) and the Chemistry-Aerosol Mediterranean Experiment (ChArMEx) projects to test the effects of ocean acidification and changes in the biogeochemistry of the seawater on the physical and chemical properties of primary marine aerosol including size distributions and CCN activity.

\section{Materials and methods}

\subsection{Measurement sites and campaigns}

Mesocosm experiments were performed during two intensive campaigns: the first, during summer oligotrophic conditions (hereafter referred to as non-bloom conditions), occurred from 22 June to 10 July 2012 at the Station de Recherches Sous-marines et Océanographiques in the Bay of Calvi (BC), Corsica; the second, performed during winter pre-bloom conditions, took place from 21 February to 5 March 2013 in the Bay of Villefranche (BV), France. The two bays share many similarities in term of temperature, salinity, phosphate $\left(\mathrm{PO}_{4}^{3-}\right)$, nitrate + nitrite $\left(\mathrm{NO}_{x}\right)$, and silicate $(\mathrm{Si})$ seasonal variations, and they both show typical bloom conditions in winter-spring and oligotrophic conditions in the summer, corresponding to a stratified water column. Pre-bloom conditions are also observed at both locations (Gazeau et al., 2015). The presence of pre-bloom and non-bloom conditions was confirmed by the order-of-magnitude difference in the average seawater chla concentrations (chla $\mathrm{BC}_{\text {, avg }}=$ $0.069 \pm 0.009 \mathrm{mg} \mathrm{m}^{-3}$, chla ${ }_{\mathrm{BV}}$ avg $=1.005 \pm 0.125 \mathrm{mg} \mathrm{m}^{-3}$ ). Detailed site and experimental information for both campaigns that legitimize the comparison to test in these two locations at different seasons can be found in Gazeau et al. (2015).

Briefly, the mesocosms used in this study (volume of $\sim 52 \mathrm{~m}^{3}$ ) were fully described in Guieu et al. (2014). The mesocosms consisted of large bags made of two $500 \mu \mathrm{m}$ thick films of polyethylene mixed with vinyl acetate (EVA, $19 \%$ ) with nylon meshing in between to allow maximum resistance and light penetration (Haikonene KY, Finland). Natural seawater was filtered through a mesh grid to remove large debris when deploying the mesocosms. In order to avoid actual atmospheric deposition, the mesocosms were covered with UV-transparent ethylene tetrafluoroethylene (ETFE) roofs, except during periods of sampling. In this way, transfer of rainwater/deposition was prevented, while preserving the sunlight irradiance of the mesocosms. The covers were elevated to $\sim 10 \mathrm{~cm}$ above the top of the mesocosms, allowing air to circulate to avoid a confinement effect in the trapped water. Among nine deployed mesocosms, three remained unmodified as controls and six were modified in terms of partial pressure of $\mathrm{CO}_{2}, p \mathrm{CO}_{2}$. The $p \mathrm{CO}_{2}$ levels used were slightly different between the two campaigns, as a consequence of different ambient $p \mathrm{CO}_{2}$ levels (i.e. $\sim 450 \mathrm{vs.}$ $350 \mu \mathrm{atm}$ at BC and BV, respectively). In the Bay of Calvi, the six targeted elevated $p \mathrm{CO}_{2}$ levels were 550, 650, 750, 850,1000 and $1250 \mu \mathrm{atm}$. In the Bay of Villefranche, the levels were 450, 550, 750, 850, 1000 and $1250 \mu \mathrm{atm}$. These elevated $p \mathrm{CO}_{2}$ levels were reached by adding varying volumes of $\mathrm{CO}_{2}$ saturated seawater to the mesocosms. At both sites, seawater was pumped from near the mesocosms and sieved onto a $5 \mathrm{~mm}$ mesh sieve in order to remove large organisms. Pure $\mathrm{CO}_{2}$ was actively bubbled through the water for several minutes in order to achieve saturation; the water was then transferred to $25 \mathrm{~L}$ plastic containers for addition to the mesocosms. Depending on the targeted $p \mathrm{CO}_{2}$ level, $50 \mathrm{~L}$ to more than $500 \mathrm{~L}$ were added. A diffusing system was used to ensure a perfect mixing of this $\mathrm{CO}_{2}$ saturated seawater inside the mesocosms. In order to minimize the stress induced by the addition of large quantities of acidified water, the acidification of the mesocosms was performed over 4 days, and the experiments started when the targeted $p \mathrm{CO}_{2}$ levels were reached. The $\mathrm{CO}_{2}$ levels were chosen in order to cover the range of atmospheric $\mathrm{CO}_{2}$ concentrations projected for the 
end of the century following various scenarios (RCP 2.6 to RCP 8.5; IPCC, 2013).

For the experiments described here, every morning approximately $5 \mathrm{~L}$ of surface water (taken within a $15 \mathrm{~cm}$ depth from the surface) was pumped from each mesocosm using a perfluoroalkoxy alkane (PFA) pump (Saint-Gobain Performance Plastics) activated by the pressurized air from a diving tank and connected to braided PVC tubing (HolzelockTricoflex, I.D. $9.5 \mathrm{~mm}$ ). The water pump was flushed with seawater from the respective mesocosm prior to sampling. Samples were stored in large brown glass bottles outside (avoiding direct sunlight) until the experiments were performed that same day. During the BV campaign, the pump could not be used on 3 March 2013 due to unsafe sea conditions; water was instead manually sampled from the mesocosms with $2.5 \mathrm{~L}$ glass bottles while wearing long gloves. Additionally, due to dangerous wind and wave conditions, sampling was not performed on 5 March 2013 during the BV campaign. Instrumental failures occurred on 4 and 10 July 2012 at BC and on 28 February-1 March 2013 at BV.

For both campaigns, the mesocosms were located offshore in pelagic waters in order to measure primary marine aerosol properties and biogeochemical parameters of the water while minimizing contamination from anthropogenic sources. The mesocosms were reached via ocean kayak or boat. For both campaigns, sampling operations were performed from a mobile plastic platform that was moved via a rope network. The water temperature variances between $\mathrm{BC}$ and $\mathrm{BV}$ are quite drastic, given the time of year the experiments took place. From conductivity, temperature and depth (CTD) measurements, at $\mathrm{BC}$ the water temperature measured nearest to the surface varied from 21.8 to $25.2^{\circ} \mathrm{C}$; at $\mathrm{BV}$, the temperatures ranged from 13.0 to $13.6^{\circ} \mathrm{C}$.

For the experiments described here, we focused on three different mesocosms: control mesocosm C3, and acidified mesocosms P3 and P6. Mesocosm P6 was the most acidified of all mesocosms ( $\left.p \mathrm{CO}_{2} \sim 1250 \mu \mathrm{atm}\right)$, and $\mathrm{P} 3$ was acidified to an intermediate level $\left(p \mathrm{CO}_{2} \sim 750 \mu \mathrm{atm}\right)$. This allowed a range of acidification effects to be analyzed.

\subsection{Experimental methods}

Bubble-bursting experiments were performed using a square glass tank $\left(201 \times 20 \mathrm{~W} \times 25 \mathrm{~h} \mathrm{~cm}^{3}\right)$, filled with $3.6 \mathrm{~L}$ of seawater (water depth of $\sim 10 \mathrm{~cm}$ ), sealed with a stainless steel lid and continuously flushed with particle-free air $\left(11 \mathrm{Lmin}^{-1}\right)$. The tank was constantly slightly overpressured with particle-free air to ensure the absence of ambient room air. Aerosols were generated by splashing mesocosm seawater through plunging water jets, separated into eight jets via a flow distributor. The mesocosm seawater was re-circulated using a peristaltic pump; to minimize an increasing temperature of the seawater caused by constant recirculation, a stainless steel heat exchanger was used on the seawater exiting the pump. The temperature of the water was recorded with a temperature sensor at the beginning and end of each experiment (for the BV campaign). Since no measurements of the bubble size distribution could be performed in such a small device, all water flow characteristics were performed according to the Fuentes et al. (2010a) settings, to reproduce the same bubble size distribution. The water flow rate was set to $1.8 \mathrm{Lmin}^{-1}$, the height of the jets above the water surface was $9 \mathrm{~cm}$ and the penetration depth of the jets was $\sim 7.5 \mathrm{~cm}$. Particle-free air was blown over the seawater (using a j-shaped tube $\sim 1.5 \mathrm{~cm}$ above the water surface) to mimic the wind blowing effect on the bubble-bursting process. Some of the water samples were also enriched by the addition of an organic rich microlayer from the same mesocosms (average $100 \mathrm{~mL}$, range $50-170 \mathrm{~mL}$ ). The enriched mesocosm samples were tested after the un-enriched sample to compare the effect of additional organic species.

Blank measurements were performed during the first $10 \mathrm{~min}$ of each experiment by verifying the aerosol concentration was zero in the particle-free air flushed tank. Between each water sample testing, the aquarium and tubing were rinsed with ultrapure water $(>18 \mathrm{M} \Omega \mathrm{cm})$, and clean water was re-circulated throughout the experimental setup for 10$15 \mathrm{~min}$. Experiments were performed on the mesocosm water in different orders each day to make sure there were no experimental biases.

The aerosol flow was passed through a diffusion drier and was sent through a neutralizer into a differential mobility particle sizer (DMPS) and miniature continuous-flow streamwise thermal-gradient $\mathrm{CCN}$ chamber $(\mathrm{CCNc})$ (Roberts and Nenes, 2005) to determine particle CCN activation properties. The neutralizer used was a variable-amplitude corona discharge which charges particles to the equilibrium charge distribution (Stommel and Riebel, 2004, 2005). For the BC experiments, the neutralizer voltage was $\sim 2.8 \mathrm{kV}$ and for $\mathrm{BV}, \sim 2.0 \mathrm{kV}$.

For the CCNc-DMPS system, aerosol flow passed first through a TSI-type DMA (length $44 \mathrm{~cm}$ ) selecting particle sizes in 26 channels ranging from 10 to $400 \mathrm{~nm}$ by stepping the voltage over an integration time of about $8.5 \mathrm{~min}$. Immediately after the DMA, the aerosol flow was split between the CCNc and a TSI CPC model 3010. The DMA sheath flow rate was $9 \mathrm{~L} \mathrm{~min}^{-1}$, and the sample flow rate was $1 \mathrm{Lmin}^{-1}$ in BC; 7.5 and $1.35 \mathrm{Lmin}^{-1}$ were used in BV. For the $\mathrm{BV}$ campaign, the aerosol flow was split $1 \mathrm{~L} \mathrm{~min}^{-1}$ for the CPC and $0.35 \mathrm{Lmin}^{-1}$ to the CCNc. In the CCNc, a total aerosol flow rate of $100 \mathrm{sccm}$ with a sheath-to-aerosol flow ratio of 5 was used. The $\mathrm{CCNc}$ operated at specific temperature gradient (dT) settings, testing two different supersaturations (SSs). For the BC campaign, a temperature gradient of $6^{\circ} \mathrm{C}$ (dT6) was used in the column and the top temperature of the column varied as the ambient temperature changed $\left(T_{\text {top }}-T_{\mathrm{amb}}=2{ }^{\circ} \mathrm{C}\right)$; in $\mathrm{BV}$, dT6 and a temperature gradient of $3{ }^{\circ} \mathrm{C}(\mathrm{dT} 3)$ were tested and the top temperature of the column was always set at $30^{\circ} \mathrm{C}$. The data are plotted as activated fraction vs. particle diameter and fit with 
a sigmoid curve, from which we obtain the activation diameter at each dT (see Asmi et al., 2012 for more details). The CCNc system was calibrated with atomized $\left(\mathrm{NH}_{4}\right)_{2} \mathrm{SO}_{4}$ and $\mathrm{NaCl}$ solutions at the beginning, end and throughout each campaign. The activation diameter of the calibration was then used to calculate the corresponding supersaturation; this supersaturation was then used for all mesocosm experiments. The activation diameters and corresponding supersaturations for each dT for both campaigns are shown in Table $1(\mathrm{dT} 6=0.39 \% \mathrm{SS}, \mathrm{dT} 3=0.08 \%)$. The range of SS values used in this work is typical of those reported in natural clouds. Anttila et al. (2009) found cloud SS values from 0.18 to $0.26 \%$ for low-level clouds in northern Finland, Hegg et al. (2009) obtained a SS range from 0.2 to $0.3 \%$ for clouds over the California coast, and Asmi et al. (2012) found SS values from 0.1 to $0.3 \%$ at the puy-de-Dôme station in central France.

\subsection{Seawater parameters}

Every day at 8:30 (LT), depth-integrated sampling (0-10 m) was performed in each mesocosm using $5 \mathrm{~L}$ Hydro-Bios integrated water samplers. Samples for pigment analyses were filtered ( $2 \mathrm{~L}$ ) onto GF/F. Filters were directly frozen with liquid nitrogen and stored at $-80^{\circ} \mathrm{C}$. Measurements were performed on an HPLC from filters extracted in $100 \%$ methanol, disrupted by sonication and clarified by filtration (GF/F Whatman). Samples for microbial diversity $(2 \mathrm{~mL}$ ) were fixed with $0.5 \%$ final concentration glutaraldehyde, frozen in liquid nitrogen, and then transferred to a $-80^{\circ} \mathrm{C}$ freezer. Virus-like particles, heterotrophic and autotrophic prokaryotes abundances were measured with the use of Flow Cytometry (Beckton Dickinson FACS Calibur model). Total organic carbon (TOC) was measured instead of dissolved organic carbon (DOC) in order to avoid contamination during filtration. However, the TOC measurement is referred to hereafter as DOC, due to the low concentration of particulate organic carbon in both sites (averaged over all mesocosms and all sampling times, BC: $4.32 \pm 0.91 \mu \mathrm{Mol}$, BV: $11.49 \pm 5.50 \mu \mathrm{Mol}$, which was typically less than $10 \%$ of TOC). DOC concentrations were determined on $20 \mathrm{~mL}$ samples by high temperature oxidation with a Shimadzu 5000A TOC Analyzer. Transparent exopolymeric particle (TEP) concentrations were measured spectrophotometrically according to a dye-binding assay (Engel, 2009). Samples $(250 \mathrm{~mL})$ were filtered onto $0.4 \mathrm{~mm}$ pore size polycarbonate filters under low vacuum $(<100 \mathrm{~mm} \mathrm{Hg})$, stained with $1 \mathrm{~mL}$ of Alcian blue solution $(0.02 \mathrm{~g}$ Alcian blue in $100 \mathrm{~mL}$ of acetic acid solution of $\mathrm{pH} 2.5$ ) and rinsed with $1 \mathrm{~mL}$ of distillate water. Filters were then soaked for $3 \mathrm{~h}$ in $6 \mathrm{~mL}$ of $80 \%$ sulfuric acid $\left(\mathrm{H}_{2} \mathrm{SO}_{4}\right)$ to dissolve the dye, and the absorbance of the solution was measured at $787 \mathrm{~nm}$, using acidic polysaccharide xanthan gum as a standard.
Table 1. Calibration information at varying temperature gradients for $\mathrm{NaCl}\left(35 \mathrm{gL}^{-1}\right)$ in tank.

\begin{tabular}{ccc}
\hline $\begin{array}{c}\text { Temperature } \\
\text { gradient }\end{array}$ & $\begin{array}{c}\text { Activation } \\
\text { diameter } \\
(\mathrm{nm})\end{array}$ & $\begin{array}{c}\text { Supersaturation, } \\
\text { SS }(\%)\end{array}$ \\
\hline dT6 & $42.497 \pm 1.82$ & 0.39 \\
dT3 & $122.915 \pm 8.65$ & 0.08 \\
\hline
\end{tabular}

\section{Results and discussion}

In studying the effects of ocean acidification, it was necessary to observe whether changes with biogeochemical processes affected primary marine aerosol emissions and chemical and physical aerosol properties. For many of the parameters studied (e.g. chla concentrations, total prokaryotic cells and virus-like particles abundances), there were no strong discernible differences between the control, $\mathrm{C} 3$, or the acidified mesocosms, P3 and P6, along the course of the experiments; however, there were often large differences between the two campaigns due to the pre-bloom and non-bloom conditions. While several studies have shown the effects of ocean acidification on biogeochemical parameters in eutrophic waters (Galgani et al., 2014; Schulz et al., 2013), observations from the MedSea experiment showed no effect of ocean acidification on most of the biogeochemical parameters in these oligo- to mesotrophic areas. These results are discussed more fully in Gazeau et al. (2015). As a consequence, we did not expect any impact on the primary marine aerosol physical aerosol properties. In the following sections, we will relate trends observed with different biogeochemical parameters to those observed in the primary marine aerosol.

\subsection{Aerosol size distributions and number concentration}

The marine aerosol size distributions remained fairly stable during a given experiment, which lasted around $1 \mathrm{~h}$ for each water sample. The aerosol size distribution also remained stable throughout the course of each campaign, with a similar distribution shape. Four lognormal modes were fit to the average size distributions of each campaign, with results summarized in Fig. 1 and Table 2. The average size distributions were taken from 214 size distributions for $\mathrm{BC}$ and 182 size distributions for $\mathrm{BV}$, and size envelopes are also included within Fig. 1. In order to investigate the size of the aerosol independently of the concentration, the size distributions were normalized using the total aerosol number concentration. We found that the primary marine aerosol size distributions were best described using the three expected modes: nucleation mode (around $20 \mathrm{~nm}$ ), Aitken mode (around $40 \mathrm{~nm}$ ), and accumulation mode (around $100 \mathrm{~nm}$ ); and an additional fourth mode around $260 \mathrm{~nm}$. Using only three modes for the fitting procedure could not satisfactorily represent the primary ma- 
Table 2. Modal diameter $(\mathrm{nm})$ and number fraction averages from the size distributions for both campaigns, including data from both supersaturations and microlayer enriched experiments. Lognormal modal diameters and number fractions from Fuentes et al. (2010a) are also shown.

\begin{tabular}{|c|c|c|c|c|c|c|}
\hline & \multicolumn{2}{|c|}{$\begin{array}{c}\mathrm{BC} \\
(\mathrm{SS}=0.39 \% \text { and enriched })\end{array}$} & \multicolumn{2}{|c|}{$\begin{array}{c}\mathrm{BV} \\
(\mathrm{SS}=0.39 \%+0.08 \% \text { and enriched })\end{array}$} & \multicolumn{2}{|c|}{$\begin{array}{c}\text { Artificial sea water } \\
\text { Fuentes et al. (2010a) }\end{array}$} \\
\hline & Diameter & Fraction & Diameter & Fraction & Diameter & Fraction \\
\hline Mode 1 & $17 \pm 1.2$ & 0.32 & $20 \pm 0.07$ & 0.19 & 14 & 0.38 \\
\hline Mode 2 & $38 \pm 1.3$ & 0.30 & $37 \pm 2.5$ & 0.48 & 48 & 0.32 \\
\hline Mode 3 & $91 \pm 2.1$ & 0.27 & $92 \pm 3.4$ & 0.24 & 124 & 0.17 \\
\hline Mode 4 & $260 \pm 2.0$ & 0.11 & $260 \pm 6.0$ & 0.09 & 334 & 0.13 \\
\hline
\end{tabular}

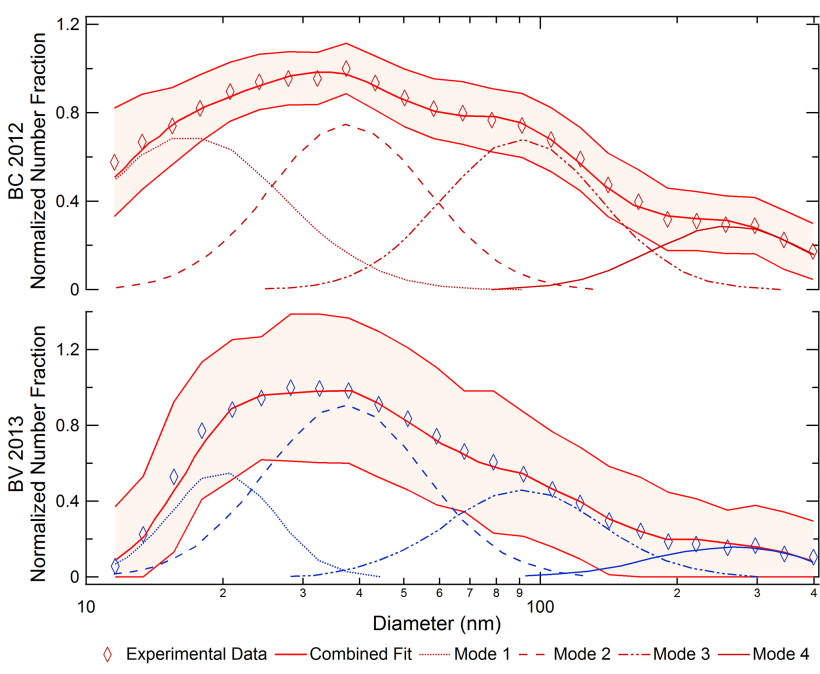

Figure 1. Average size distributions for each campaign (Bay of Calvi, BC, and Bay of Villefranche, BV) fit with four lognormal modes. Each campaign average is taken from the supersaturations ( $\mathrm{SS}=0.08 \%$ and $0.39 \%$ ) used for all three mesocosms and includes all enriched samples as well.

rine aerosol size distribution. A mode at around $300 \mathrm{~nm}$ was also found by Sellegri et al. (2006) during bubbling experiments for which the effect of wind on the surface breaking bubbles was simulated in a similar experiment set-up. The $300 \mathrm{~nm}$ mode was interpreted by the authors as the result of a thicker bubble film where the bubbles are forced to break by the wind instead of reaching a natural breaking thickness. The four average lognormal modal diameters determined $(18.5 \pm 0.6,37.5 \pm 1.4,91.5 \pm 2.0,260 \pm 3.2 \mathrm{~nm})$ were present in both $\mathrm{BC}$ and $\mathrm{BV}$. The lognormal mode fitting was also used to determine the particle number fraction at each lognormal modal diameter. Looking at the number fractions on a daily temporal scale for $\mathrm{SS}=0.39 \%$, the lognormal mode number fractions remained relatively constant throughout both campaigns, though differences were noted between the campaigns (Fig. 2, Table 2). Throughout the campaign in $\mathrm{BC}$, the fractions of Modes 1-3 were approximately equal in magnitude $(0.297)$, whereas in $\mathrm{BV}$, the

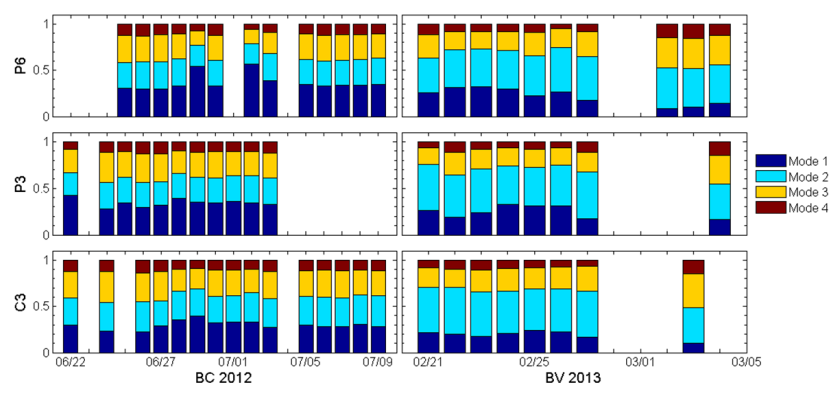

Figure 2. Number fraction of DMPS lognormal modes from all mesocosms $(\mathrm{SS}=0.39 \%)$ at $\mathrm{BC}$ and $\mathrm{BV}$.

magnitude of the Mode 2 (the Aitken mode) fraction relative to the other modes was dominant $(0.48)$. These same trends were observed for all experiments using $\mathrm{SS}=0.08 \%$ and all the enriched mesocosm samples (Figs. 3, 4). When augmenting the bacterial abundance in seawater, Collins et al. (2013) observed an increased particle fraction of the smallest lognormal mode diameter with no change to the shape or magnitude of the size distribution; this was attributed to the replacement of internally mixed salt/organic particle types by insoluble organic type particles. Previous studies have also indicated changing size distributions or mode number fractions with increasing organic material (Fuentes et al., 2010b; Sellegri et al., 2006). In the present study, we will examine which chemical component is linked to the increase of the Aitken mode particles in Sect. 3.3.

Many other studies have found different lognormal mode distributions of both artificial and natural seawater samples, though many have similar modal sizes. Differences in the size distribution of laboratory generated primary marine aerosol found in the literature seem to depend on the method used to generate them. Fuentes et al. (2010a) observed four modes (modal sizes 14, 48, 124, $334 \mathrm{~nm}$ ) generated from plunging-water jet experiments with artificial seawater. Mode 4 was believed to be linked to splashing water from the jet mechanism. Plunging-water jet experiments were found to most closely mimic the size distribution of ambient primary marine aerosol (Fuentes et al., 2010a) while 


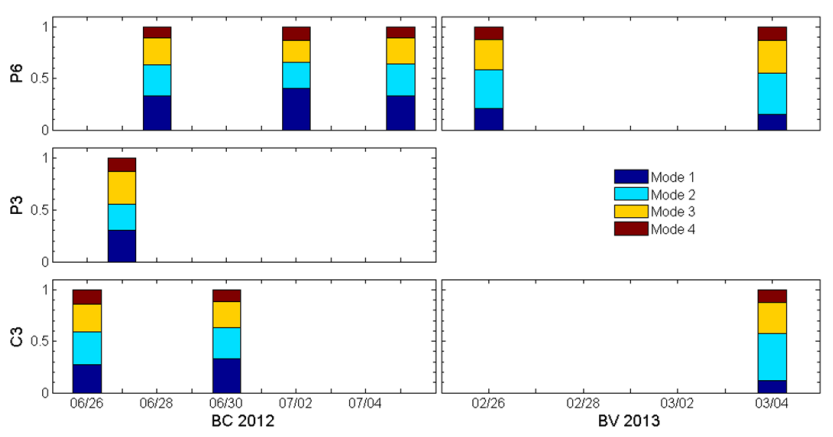

Figure 3. Number fraction of DMPS lognormal modes from microlayer enriched samples $(\mathrm{SS}=0.39 \%$ ) at $\mathrm{BC}$ and $\mathrm{BV}$.

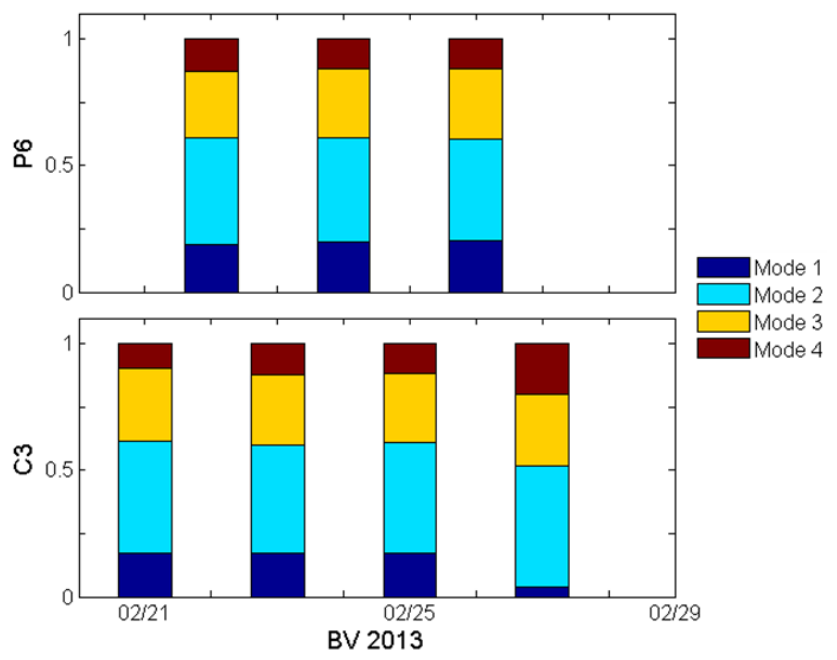

Figure 4. Number fraction of DMPS lognormal modes tested at $\mathrm{SS}=0.08 \%$ for mesocosms C3 and P6 at BV.

generating sufficient aerosol for characterization measurements. In a separate study (Fuentes et al., 2010b), four modes represented both artificial and natural seawater (modal sizes $15,45,125,340 \mathrm{~nm}$ ) well. Similar to our findings, increasing organic content was found to increase the number fraction of Mode 2 while decreasing the relative fractions of the other modes. In similar experiments with Baltic seawater collected between May and September, Hultin et al. (2011) observed either two lognormal modes (site: Askö, $86,180 \mathrm{~nm}$ ) or three lognormal modes (site: Garpen, 93, 193, $577 \mathrm{~nm}$ ). Sellegri et al. (2006) tested synthetic sea salt with a weir and observed three lognormal modes $\left(4^{\circ} \mathrm{C}: 30,85,200 \mathrm{~nm} ; 23^{\circ} \mathrm{C}\right.$ : $45,110,300 \mathrm{~nm})$. After adding SDS, they noticed an increase in the fraction of particles at the smallest lognormal diameter. In synthetic seawater experiments with sintered glass filters, Mårtensson et al. (2003) observed one submicron lognormal mode $(100 \mathrm{~nm})$; Tyree et al. (2007) observed a lognormal mode at the same diameter using artificial and natural seawater with pore diffusers. The Mårtensson et al. (2003) and Tyree et al. (2007) studies using sintered glass filters or pore diffusers report relatively different size distributions compared to those obtained by plunging jet experiments, likely due to the bubble formation processes. Collins et al. (2013) observed three lognormal modes in seawater wave channel experiments $(\sim 90,220,1000 \mathrm{~nm})$, with changing number fractions as described in the above paragraph.

Temperature has also been shown to affect size distributions and aerosol number concentrations (Hultin et al., 2011; Mårtensson et al., 2003; Zábori et al., 2012a). The initial and final water temperatures were measured over the course of an experiment ( $\sim 1 \mathrm{~h}, \mathrm{BV}$ only); the water temperature was found to increase by $4.6 \pm 1.2^{\circ} \mathrm{Ch}^{-1}$ on average due to the constant water recirculation through the peristaltic pump and an insufficient heat exchange system (encompassing all experiments, water temperatures ranged from $\sim 11.7-26.8^{\circ} \mathrm{C}$ from the initial to final measurement). This increase is 2 5 times higher than the $1-2^{\circ} \mathrm{Ch}^{-1}$ temperature increase measured by Zábori et al. (2012a). Even with this large temperature range, we did not observe that the increase in the water temperature affected the shape of the size distribution. We were not able to make qualitative statements about the relationship between the number concentration and temperature, with the level of uncertainty in the wind flow stability within these experiments. Acidification had no effect on the aerosol size distribution, as no clear differences were found between mesocosms C3, P3, and P6 within a given field campaign.

\subsection{Activation diameter}

By testing two temperature gradients, it is possible to look at the hygroscopic properties of different size particles based on the different supersaturations at which they are activated. The activation diameter time series measured at $\mathrm{SS}=0.39 \%$ (dT6) is shown in Fig. 5. In BC, there is little variation temporally between the control and acidified mesocosms tested $\left(D_{\mathrm{p}, 50 \text {, avg }}=46.47 \pm 0.88 \mathrm{~nm}\right)$, indicating that acidification does not have a large direct effect on CCN activity. Additionally, the enriched samples showed similar behavior to the non-enriched waters, indicating that the addition of the organic-rich microlayer had little effect on the water uptake for the aerosols. For the experiments incorporating the enriched microlayer, the entire organic-rich volume was added a few minutes before starting the water jet system, rather than being continuously introduced to the tank throughout the entire experiment. This could have led to microlayer depletion over the course of an experiment, explaining why no visible difference was seen between the enriched and un-enriched samples. However, no clear difference was seen between the first (when the microlayer was present) and subsequent size distributions during a given microlayer enriched experiment. In past experiments, the addition of organics to bubbling experiments have shown changes in the size distribution (Sellegri et al., 2006), particle number concentration (Fuentes et al., 2010b; King et al., 2012; Tyree et al., 2007), and CCN activity (Collins et al., 2013; 
Fuentes et al., 2011). Other experiments have shown no visible change (Moore et al., 2011) from the addition of organics, similar to the experiments performed in this study. In some studies, the concentrations and/or nature of some of the organic surfactants were unrealistic (King et al., 2012; Moore et al., 2011; Sellegri et al., 2006). At BV, the average activation diameter for $\mathrm{SS}=0.39 \%$ over the course of the experiments was $D_{\mathrm{p}, 50 \text {, avg }}=59.48 \pm 1.1 \mathrm{~nm}$ (Fig. 5), while at $\mathrm{SS}=0.08 \%$ the average activation diameter was $D_{\mathrm{p}, 50, \text { avg }}=141.91 \pm 10.8 \mathrm{~nm}$ (Fig. 6). Activation diameters larger than the corresponding salt standards (here, shown as $\mathrm{NaCl}$ ), indicating higher organic presence, are observed more at $\mathrm{BV}$ than $\mathrm{BC}$ for $\mathrm{SS}=0.39 \%$ due to the organic pre-bloom conditions, whereas the non-bloom water conditions were very stable at $\mathrm{BC}$. For $\mathrm{SS}=0.08 \%$, the activation diameters are very similar to the $\mathrm{NaCl}$ standard, which signifies a lower organic fraction for larger particles. Activation diameters for individual mesocosms in both campaigns are shown in Table 3 .

There is an anti-correlation of the activation diameter at $\mathrm{SS}=0.39 \%$ with the ambient average air temperature in BV (Fig. 5), though no correlation exists with $\mathrm{SS}=0.08 \%$ (Fig. 6), or in BC (Fig. 5). However, more daily temperature variance was observed in $\mathrm{BV}$ than $\mathrm{BC}$, based on the time of year of the campaigns. This anti-correlation could indicate an additional temperature impact on the emission of small particles $(\sim 50 \mathrm{~nm})$ and their chemical composition, though this effect is unclear and undocumented in the literature.

We investigated if the observed differences in the activation diameters from $\mathrm{BC}$ and $\mathrm{BV}$ could be linked to the different operating techniques used for the campaigns. As indicated previously, $T_{\text {top }}$ in $\mathrm{BC}$ was variable, changing as the ambient temperature changed. As the ambient temperature changed throughout the day, the temperature in the column would also change, leading to possible temperature instabilities throughout the course of an experiment. On the contrary, in $\mathrm{BV}, T_{\text {top }}$ was fixed at $30^{\circ} \mathrm{C}$, a temperature higher than the daily temperature variability. In this way, temperature fluctuations in the column were avoided. However, in observing the measured temperatures throughout the column for both campaigns and all the experiments, the temperatures of the column remained quite stable for both methods of operation, so we believe that these effects are very minor. Additionally, it has been shown that organics can volatilize in the $\mathrm{CCN}$ column due to the temperature gradient (Asa-Awuku et al., 2009), biasing observed CCN activity. It is possible that this occurred for both campaigns based on the relatively high measured operating temperatures observed in the column; if organic material was volatilized, the activation diameters would increase from those shown here.

\subsection{Kappa and organic fraction}

The hygroscopicity of the aerosol was determined using kappa-Köhler theory (Petters and Kreidenweis, 2007) fol-

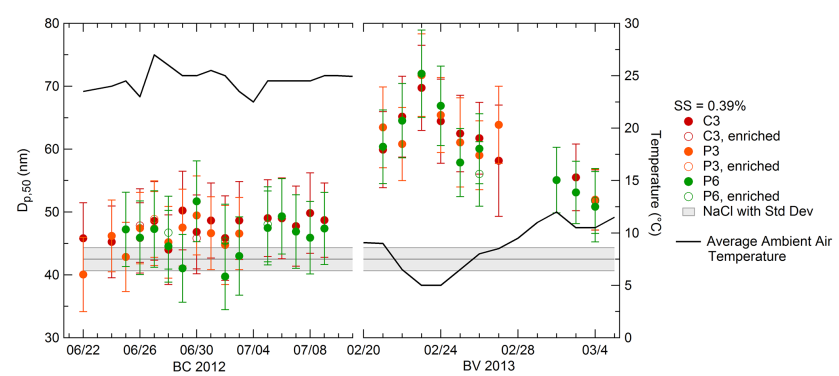

Figure 5. Activation diameter and ambient air temperatures for $\mathrm{BC}$ and BV. Data are shown for SS $=0.39 \%$ (dT6), including the microlayer enriched experiments. The shaded bar indicates the $\mathrm{NaCl}$ activation diameter.

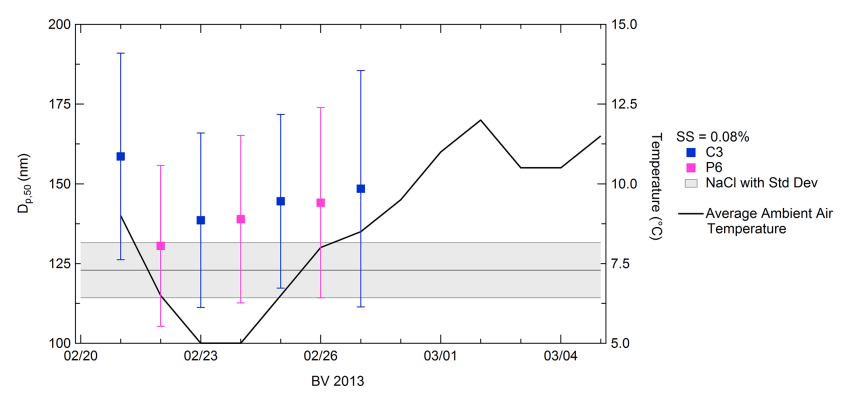

Figure 6. Activation diameter and ambient air temperatures for BV. Data are shown for $\mathrm{SS}=0.08 \%$ (dT3). The shaded bar indicates the $\mathrm{NaCl}$ activation diameter.

lowing Asmi et al. (2012). Using the activation diameter and numerical iteration, the kappa value was determined when the maximum of the saturation curve was equal to the supersaturation in the $\mathrm{CCNc}$, following,

$S\left(D_{\mathrm{p}}\right)=\frac{D_{\mathrm{p}}^{3}-D_{\mathrm{p}, 50}^{3}}{D_{\mathrm{p}}^{3}-D_{\mathrm{p}, 50}^{3}(1-\kappa)} \exp \left(\frac{4 \sigma_{\mathrm{w}} M_{\mathrm{w}}}{R T \rho_{\mathrm{w}} D_{\mathrm{p}}}\right)$,

where $S$ is the supersaturation, $D_{\mathrm{p}}$ is the diameter of the droplet, $D_{\mathrm{p}, 50}$ is the dry diameter, $R$ is the gas constant, $T$ is temperature, and $\sigma_{\mathrm{w}}, M_{\mathrm{w}}$, and $\rho_{\mathrm{w}}$ are the surface tension, molecular weight and density of water, respectively. Lower kappa values correspond to more hydrophobic, or organiclike, particles. In $\mathrm{BC}$, the average mesocosm kappa value at $\mathrm{SS}=0.39 \%$ was $\kappa_{\mathrm{avg}, \mathrm{BC}}=0.95 \pm 0.17$, In BV, the average mesocosm kappa values for $\mathrm{SS}=0.39$ and $0.08 \%$ are $\kappa_{\mathrm{avg}, \mathrm{BV}}=0.45 \pm 0.13$ and $0.78 \pm 0.14$, respectively. This indicates that the smaller particles (measured at the higher SS) were higher in organic material. The kappa values obtained at $\mathrm{SS}=0.08 \%$ are more representative of the kappa that would be obtained for a bulk chemical composition, as most of the aerosol mass is comprised in the accumulation mode for submicron particles. Our value then falls well into the suggested range of the kappa average of marine aerosol, $\kappa_{\text {marine }}=0.72 \pm 0.24$ (Pringle et al., 2010). Little variance was seen between the control and acidified mesocosms. 
Table 3. Average activation diameters, $\kappa$ values and organic fractions for both campaigns and supersaturations.

\begin{tabular}{|c|c|c|c|c|c|}
\hline & & Mesocosm & Activation diameter $(\mathrm{nm})$ & $\kappa$ & Organic fraction \\
\hline \multirow{6}{*}{$\mathrm{BC}$} & \multirow{6}{*}{$\mathrm{SS}=0.39 \%$} & $\mathrm{C} 3$ & $47.5 \pm 1.6$ & $0.88 \pm 0.11$ & $0.29 \pm 0.09$ \\
\hline & & $\mathrm{C} 3$, enriched & $46.8 \pm 4.1$ & $0.92 \pm 0.08$ & $0.26 \pm 0.07$ \\
\hline & & P3 & $45.8 \pm 1.8$ & $1.00 \pm 0.19$ & $0.20 \pm 0.16$ \\
\hline & & P3, enriched & $48.9 \pm 6.1$ & $0.81 \pm 0$ & $0.35 \pm 0$ \\
\hline & & P6 & $45.7 \pm 1.6$ & $1.00 \pm 0.23$ & $0.20 \pm 0.18$ \\
\hline & & P6, enriched & $46.7 \pm 3.4$ & $0.93 \pm 0.08$ & $0.26 \pm 0.06$ \\
\hline \multirow{10}{*}{ BV } & \multirow{7}{*}{$\mathrm{SS}=0.39 \%$} & $\mathrm{C} 3$ & $61.8 \pm 2.2$ & $0.40 \pm 0.09$ & $0.68 \pm 0.07$ \\
\hline & & $\mathrm{C} 3$, enriched & $51.9 \pm 4.8$ & $0.68 \pm 0$ & $0.46 \pm 0$ \\
\hline & & P3 & $61.2 \pm 2.1$ & $0.41 \pm 0.12$ & $0.67 \pm 0.10$ \\
\hline & & P6 & $59.1 \pm 1.9$ & $0.47 \pm 0.15$ & $0.63 \pm 0.12$ \\
\hline & & P6, enriched & $53.9 \pm 3.6$ & $0.61 \pm 0.10$ & $0.52 \pm 0.08$ \\
\hline & & Outside & $54.2 \pm 3.6$ & $0.59 \pm 0.14$ & $0.53 \pm 0.11$ \\
\hline & & Outside, enriched & $55.5 \pm 3.0$ & $0.55 \pm 0.07$ & $0.56 \pm 0.05$ \\
\hline & \multirow{3}{*}{$\mathrm{SS}=0.08 \%$} & $\mathrm{C} 3$ & $146.0 \pm 16.6$ & $0.72 \pm 0.14$ & $0.43 \pm 0.12$ \\
\hline & & $\mathrm{C} 3$, enriched & $148.5 \pm 37.1$ & $0.69 \pm 0$ & $0.45 \pm 0$ \\
\hline & & P6 & $137.1 \pm 15.5$ & $0.87 \pm 0.13$ & $0.31 \pm 0.11$ \\
\hline
\end{tabular}

Using the calculated kappa values, we determined the organic fraction using a kappa closure equation,

$\kappa_{\text {total }}=\varepsilon_{\text {org }} \kappa_{\text {org }}+\left(1-\varepsilon_{\text {org }}\right) \kappa_{\text {inorg }}$

where $\varepsilon_{\text {org }}$ is the bulk volume fraction of organic material and $\kappa$ is the kappa of the organic or inorganic material. Following Collins et al. (2013), we used $\kappa_{\text {inorg }}=1.25$, a good proxy for seawater, and $\kappa_{\text {org }}=0.006$. In BC, the organic fraction ranged from -0.21 to 0.46 (average, $0.24 \pm 0.14$ ) for $\mathrm{SS}=0.39 \%$. For $\mathrm{BV}$, the organic fraction ranged from 0.43 to 0.80 (average, $0.64 \pm 0.11$ ) for $\mathrm{SS}=0.39 \%$ and from 0.19 to 0.55 (average, $0.38 \pm 0.11$ ) for $\mathrm{SS}=0.08 \%$. Previous studies have also found mass organic fractions ranging from 30 to $80 \%$ in sea spray aerosol studies of water from the North Atlantic, Sargasso Sea near Bermuda, and Pacific water near La Jolla, California (Collins et al., 2013; Facchini et al., 2008; Keene et al., 2007). Negative organic fractions were calculated during the $\mathrm{BC}$ campaign due to the sensitivity of Eq. (2) to the value of $\kappa_{\text {inorg }}$ over $\kappa_{\text {org. }}$. We show results here using a $\kappa_{\text {inorg }}$ value supported by literature rather than determine non-realistic $\kappa_{\text {inorg }}$ values to provide positive organic fractions. Therefore, the values shown in this work can be considered low estimates of the organic fraction. Table 3 shows average kappa and organic fraction values of each mesocosm for both campaigns.

The organic fraction of the Aitken mode particles (obtained from measurements performed at $\mathrm{SS}=0.39 \%$ ) is significantly increased during the $\mathrm{BV}$ experiment compared to the $\mathrm{BC}$ experiment. This indicates that the Mode 2 fraction increase observed in the size distribution is due to the presence of organic matter, in agreement with the observations of Collins et al. (2013).
The ratio of cloud condensation nuclei $(\mathrm{CCN})$ to condensation nuclei $(\mathrm{CN})$ decreased slightly during the prebloom period for $\mathrm{SS}=0.39 \%$ : at $\mathrm{BC}, \mathrm{CCN} / \mathrm{CN}_{\text {average }}=$ $0.55 \pm 0.03$, whereas at $\mathrm{BV}, \mathrm{CCN} / \mathrm{CN}_{\text {average }}=0.45 \pm 0.07$. The change between $\mathrm{CCN} / \mathrm{CN}$ during the oligotrophic and pre-bloom conditions was likely due to the combined effects of a higher organic fraction and higher Mode 2 to Mode 1 ratio during pre-bloom conditions, likely caused by the increasing organic content of the water due to the prebloom. For $\mathrm{SS}=0.08 \%$ measured at $\mathrm{BV}, \mathrm{CCN} / \mathrm{CN}_{\text {average }}=$ $0.15 \pm 0.02$.

\subsection{Correlations with biological parameters}

In a recent study, Rinaldi et al. (2013) showed that chla was the best biological surrogate for predicting organic enrichment in sea spray. Chla parameterizations are currently being used in models to account for the organic content of seawater. We find a strong linear correlation with same-day measurements of organic fraction (from SS $=0.39 \%$ ) and total chla concentrations $\left(R^{2}=0.781, p<0.00001\right)$ shown in log-log scale in Fig. 7, following

Organic fraction $[\%]=42.28 \cdot(\mathrm{chla})\left[\mathrm{mg} \mathrm{m}^{-3}\right]+22.98$.

Similar correlations were also found with a number of pigments: chlorophyll $\mathrm{c} 1+\mathrm{c} 2\left(R^{2}=0.783, p<0.00001\right)$, $19^{\prime}$-butanoyloxyfucoxanthin $\quad\left(R^{2}=0.711, \quad p<0.00001\right)$, alloxanthin $\left(R^{2}=0.699, \quad p<0.00001\right)$, sum carotenes $\left(R^{2}=0.773, p<0.00001\right)$ and $19^{\prime}$-hexanoyloxyfucoxanthin $\left(R^{2}=0.736, p<0.00001\right)$ (Fig. 8). Various studies have found linear correlations between the organic fraction of aerosols measured at a receptor site and chla concentrations observed by satellite along the back trajectory (Langmann et 


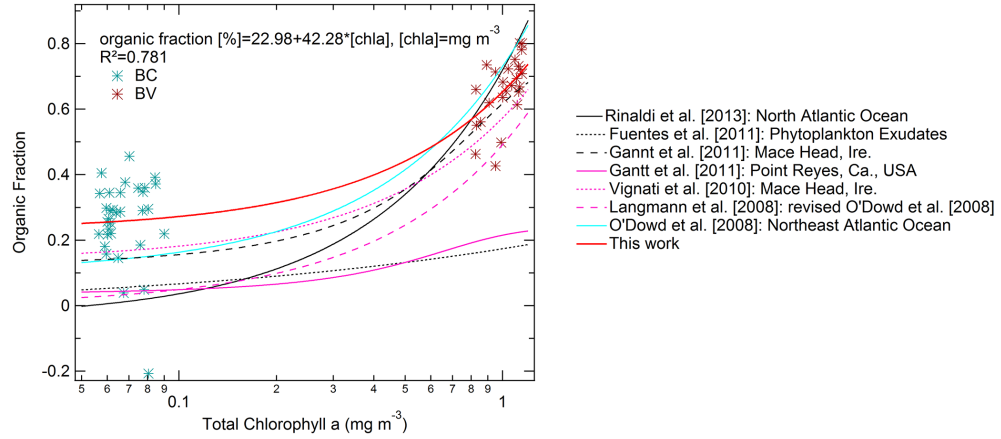

Figure 7. Organic fraction calculated from kappa ( $\kappa_{\mathrm{org}}=0.006$ and $\left.\kappa_{\text {inorg }}=1.25\right)$ at $\mathrm{SS}=0.39 \%$ vs. total chlorophyll $a$ concentrations $\left(\mathrm{mg} \mathrm{m}^{-3}\right)$ for all three mesocosms during both $\mathrm{BC}$ and $\mathrm{BV}$, fit with published parameterizations of the organic fraction-chla relationship.
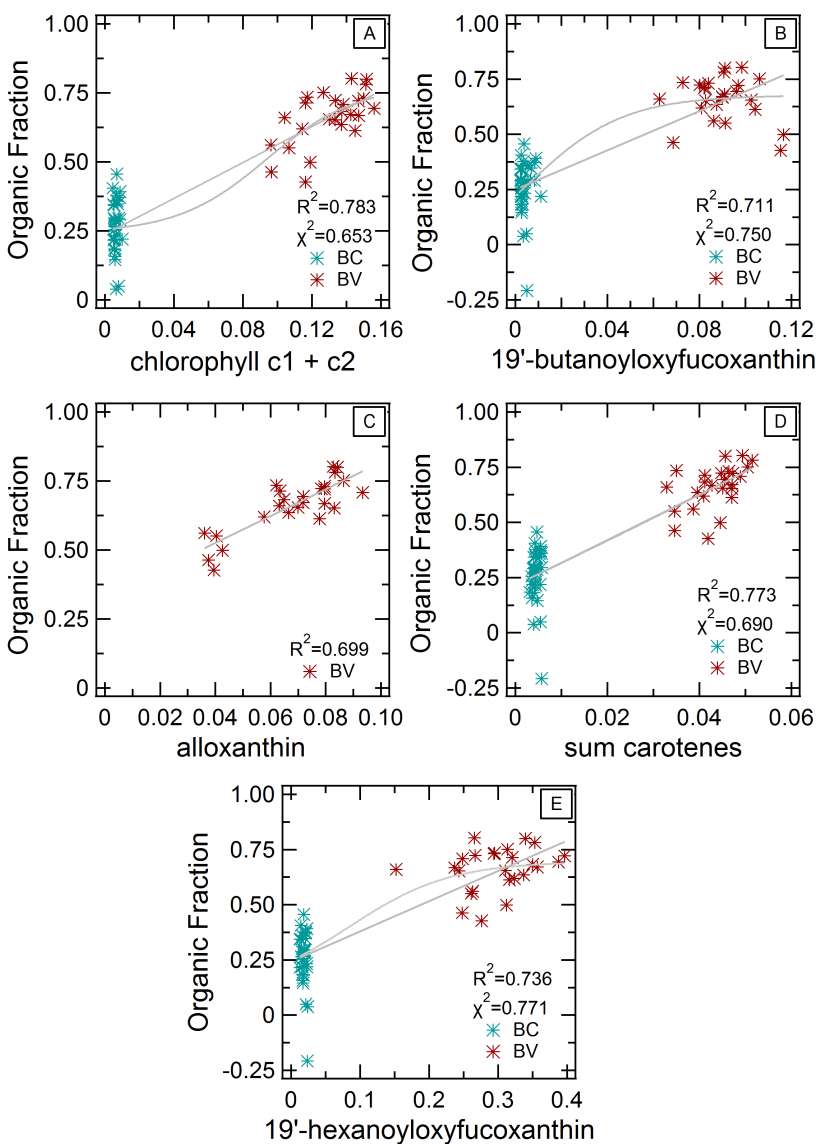

Figure 8. Organic fraction calculated from kappa $\left(\kappa_{\mathrm{org}}=0.006\right.$ and $\left.\kappa_{\text {inorg }}=1.25\right)$ at $\mathrm{SS}=0.39 \%$ vs. chlorophyll $\mathrm{c} 1+\mathrm{c} 2(\mathbf{a}), 19^{\prime}-$ butanoyloxyfucoxanthin (b), alloxanthin (c), sum carotenes (d) and $19^{\prime}$-hexanoyloxyfucoxanthin (e) concentrations $\left(\mathrm{mg} \mathrm{m}^{-3}\right)$ for all three mesocosms during both $\mathrm{BC}$ and $\mathrm{BV}$. Linear fits with $R^{2}$ values are shown for all figures, and sigmoid fits with $\chi^{2}$ values are shown for all panels except for (c)

al., 2008; O’Dowd et al., 2008; Rinaldi et al., 2013; Vignati et al., 2010); others have found exponential fittings (Gantt et al., 2011) with the same methodology or a Langmuir func- tional relationship (Long et al., 2011) using a model with experimental data from Facchini et al. (2008) and Keene et al. (2007). Figure 7 shows many of the existing chla-organic fraction parameterizations in the literature, including this work. It is clear that many of the parameterizations from the North Atlantic Ocean also describe the correlation in the Mediterranean Sea fairly well, even though the methodologies for most of them are very different from the one used in this study. The parameterization derived in this work lays at higher organic content when compared to the other parameterizations, even though it does not include secondary organic contributions as do many of the satellite-receptor site studies. This is likely due to the size dependence of the organic fraction that we observed in the BV data. Our parameterization is applicable for Aitken mode type aerosols and would probably shift towards lower organic content for accumulation mode particles. It is also possible that organic components in Mediterranean primary marine aerosol are of multiple origins and not solely linked linearly to chla-rich species. Bacteria have also been observed to affect the organic material in seawater (Gruber et al., 2006; Jiao et al., 2010; Ogawa et al., 2001). We find a correlation with heterotrophic prokaryotes $\left(R^{2}=0.476, \quad p=1.3 \times 10^{-5}\right)$, virus-like particles $\left(R^{2}=0.161, p=0.025\right)$, autotrophic prokaryotes $\left(R^{2}=0.499, p<0.00001\right)$ and Synechococcus abundance $\left(R^{2}=0.143, p=0.033\right)$, shown in Fig. 9a-d. In a wave channel experiment on natural seawater doped with Zobell growth medium, bacteria and phytoplankton (Dunaliella tertiolecta) cultures, Prather et al. (2013) also observed a link between heterotrophic bacteria and organic fraction while no correlation with chla was found, highlighting the necessity to study complex systems of all biological material (phytoplankton, prokaryotes, organic matter) for marine aerosol. Most likely, the observed differences between Prather et al. (2013) and this work have to do with the localized biogeochemical nature of the different experiments, causing variance in the chemical composition and organic fraction of the marine aerosol. An additional correlation $\left(R^{2}=0.477, p=1.2 \times 10^{-5}\right)$ exists with TEPs 

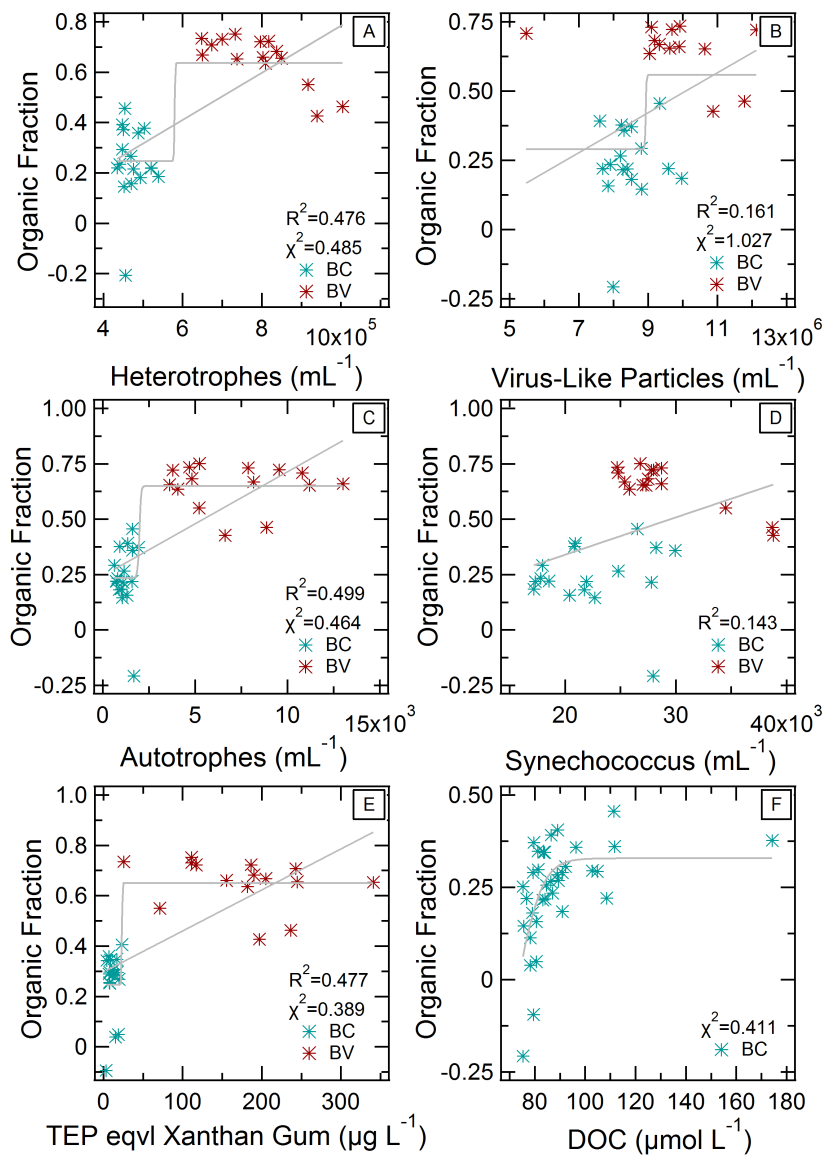

Figure 9. Organic fraction calculated from kappa $\left(\kappa_{\mathrm{org}}=0.006\right.$ and $\left.\kappa_{\text {inorg }}=1.25\right)$ at SS $=0.39 \%$ vs. heterotrophic prokaryotes (a), virus-like particles (b), autotrophic prokaryotes (c), and Synechococcus (d) abundances, and TEP equivalent (xanthan gum) (e), and DOC (f) concentrations for all three mesocosms during both $\mathrm{BC}$ and $\mathrm{BV}$. Linear fits with $R^{2}$ values are shown for all figures except for (f), and sigmoid fits with $\chi^{2}$ values are shown for all panels except for $(\mathbf{d})$.

(Fig. 9e), a surface-active complex, variable mixture of organics (Filella, 2014; Passow, 2012). During BC, there is also a sigmoidal correlation between organic fraction and DOC concentrations $\left(\chi^{2}=0.411, p<0.00003\right)$; data are unavailable for BV (Fig. 9f). Sigmoid fits are also shown in Figs. 8 and 9 for all biological parameters where they could be determined. Sigmoid fits might be more appropriate to use in many cases, to conceptually constrain the organic fraction of the primary marine aerosol to one regardless of the chla concentration. We have included both linear and sigmoid fits, with their respective $R^{2}$ and $\chi^{2}$ values for completeness.

We also wanted to see if correlations existed between different biogeochemical parameters and the temporal relative mode fractions shown in Fig. 2. Relative fractions of Modes 3 and 4 (91.5 and $260 \mathrm{~nm}$, respectively) showed no clear correlations to any parameter. However, strong anti-correlations were observed between the Mode $1(18.5 \mathrm{~nm})$ relative fraction and the abundances and concentrations of virus-like particles, heterotrophic prokaryotes and all pigments previously discussed, except for alloxanthin, which had a positive correlation (correlations not shown). The relative fraction of Mode $2(37.5 \mathrm{~nm})$ showed strong positive correlations with the abundances and concentrations of virus-like particles, heterotrophic prokaryotes, TEPs and all the pigments discussed, except for alloxanthin, where no correlation was observed (correlations not shown). This further supports the idea of an increase in the Mode 2 (Aitken mode) relative fraction during periods of high biological activity due to the higher concentrations of organic material, at the expense of Mode 1.

The control and acidified mesocosms showed no significant differences in terms of correlations between organic fraction and different biogeochemical parameters. For studies of marine aerosol, this indicates that any acidification effects on these biological parameters impacts the physical and chemical parameters of the aerosol much less than the natural variances caused by organic pre-bloom and bloom periods. It is not yet clear whether this observation can extend beyond the western Mediterranean Sea. However, it is important to note that due to the oligotrophic nature of the Mediterranean, even during the pre-bloom conditions at $\mathrm{BV}$, the chla concentrations and abundances of other parameters are still much lower than could occur in places like the North Atlantic Ocean.

\section{Conclusions}

By performing marine aerosol bubble-bursting experiments over two large-scale campaigns, we were able to compare the effects of ocean acidification during pre-bloom and oligotrophic conditions on physical and chemical properties of Mediterranean Sea aerosol. It is important to note that there are additional effects, such as wind speed, precipitation levels, and temperatures, that could change with future climate change and that these were not included within this analysis; instead, we focused on ocean acidification effects on Mediterranean Sea plankton communities and subsequent effects on primary marine aerosol. Future studies will need to incorporate additional parameters to determine further effects on primary marine aerosol. Ocean acidification had no direct effect on the physical parameters (size distribution, mode diameter and number fraction) measured in either campaign, with similar trends seen for all three differently acidified mesocosms. Additionally, experiments including the enriched sea surface microlayer, which increased organic concentrations, showed no marked difference from the unenriched mesocosm samples, indicating that enrichment did not influence the water uptake of the primary aerosol at the thermodynamic equilibrium reached in the $\mathrm{CCN}$ chamber. 
Pre-bloom conditions at BV showed marked increases in the activation diameters and organic fractions $(\sim 64 \%)$ for all the mesocosms at $\mathrm{SS}=0.39 \%$ compared to non-bloom conditions at $\mathrm{BC}(\sim 24 \%)$. At BV, larger particles $(\mathrm{SS}=0.08 \%)$ had smaller organic fractions $(\sim 38 \%)$. The organic fraction was strongly correlated with chla and additional pigment concentrations, with weaker correlations observed for heterotrophic and autotrophic prokaryotes, virus-like particles, and Synechococcus abundances, and TEPs and DOC concentrations. Many of these correlations corresponded specifically with the increase in Mode 2 (the Aitken mode) and were anti-correlated with Mode 1 during the pre-bloom period. The $\mathrm{CCN} / \mathrm{CN}_{\text {average }}$ ratio also decreased during the pre-bloom period at $\mathrm{BV}$ as a probable consequence of the increased organic content during a pre-bloom period. The parameterization of the primary marine aerosol organic fraction as a function of chla derived in the present work is a high estimate compared to the gathered parameterizations from the literature (with a higher organic fraction for a given chla content), which may confirm that species other than chla-rich species contribute to the organic content of marine aerosols in the Mediterranean atmosphere.

Author contributions. K. Sellegri, F. Gazeau, C. Guieu designed the experiments and A. N. Schwier, C. Rose, E. Asmi, K. Sellegri carried them out. Enriched microlayer data were provided by A. M. Ebling and W. M. Landing; pigment data were provided by A. Sallon and F. Gazeau; TEPs data were provided by S. Marro, M.L. Pedrotti, F. Iuculano, and S. Agusti; bacteria and virus data were provided by S. Marro, M.-L. Pedrotti, A. Tsiola, and P. Pitta; and DOC data were provided by J. Louis and C. Guieu. A. N. Schwier and K. Sellegri prepared the manuscript with contributions from all co-authors.

Acknowledgements. This work was supported by the MISTRALS/ChArMEx project and by the EC FP7 project "Mediterranean Sea Acidification in a changing climate" (MedSeA; grant agreement 265103).

Edited by: C. Reeves

\section{References}

Albert, M. F. M. A., Schaap, M., Manders, A. M. M., Scannell, C., O'Dowd, C. D., and de Leeuw, G.: Uncertainties in the determination of global sub-micron marine organic matter emissions, Atmos. Environ., 57, 289-300, 2012.

Anttila, T., Vaattovaara, P., Komppula, M., Hyvärinen, A.-P., Lihavainen, H., Kerminen, V.-M., and Laaksonen, A.: Sizedependent activation of aerosols into cloud droplets at a subarctic background site during the second Pallas Cloud Experiment (2nd PaCE): method development and data evaluation, Atmos. Chem. Phys., 9, 4841-4854, doi:10.5194/acp-9-4841-2009, 2009.
Archer, S. D., Kimmance, S. A., Stephens, J. A., Hopkins, F. E., Bellerby, R. G. J., Schulz, K. G., Piontek, J., and Engel, A.: Contrasting responses of DMS and DMSP to ocean acidification in Arctic waters, Biogeosciences, 10, 1893-1908, doi:10.5194/bg10-1893-2013, 2013.

Asa-Awuku, A., Engelhart, G. J., Lee, B. H., Pandis, S. N., and Nenes, A.: Relating CCN activity, volatility, and droplet growth kinetics of $\beta$-caryophyllene secondary organic aerosol, Atmos. Chem. Phys., 9, 795-812, doi:10.5194/acp-9-795-2009, 2009.

Asmi, E., Freney, E., Hervo, M., Picard, D., Rose, C., Colomb, A., and Sellegri, K.: Aerosol cloud activation in summer and winter at puy-de-Dôme high altitude site in France, Atmos. Chem. Phys., 12, 11589-11607, doi:10.5194/acp-12-11589-2012, 2012.

Ault, A. P., Moffet, R. C., Baltrusaitis, J., Collins, D. B., Ruppel, M. J., Cuadra-Rodriguez, L. A., Zhao, D., Guasco, T. L., Ebben, C. J., Geiger, F. M., Bertram, T. H., Prather, K. A., and Grassian, V. H.: Size-dependent changes in sea spray aerosol composition and properties with different seawater conditions, Environ. Sci. Technol., 47, 5603-5612, 2013.

Barger, W. R. and Garrett, W. D.: Surface Active Organic Material in the Marine Atmosphere, J. Geophys. Res., 75, 4561-4566, 1970.

Bates, T. S., Quinn, P. K., Frossard, A. A., Russell, L. M., Hakala, J., Petäjä, T., Kulmala, M., Covert, D. S., Cappa, C. D., Li, S.-M., Hayden, K. L., Nuaaman, I., Mclaren, R., Massoli, P., Canagaratna, M. R., Onasch, T. B., Sueper, D., Worsnop, D. R., and Keene, W. C.: Measurements of ocean derived aerosol off the coast of California, J. Geophys. Res., 117, D00V15, doi:10.1029/2012JD017588, 2012.

Benner, R.: Chemical composition and reactivity, in: Biogeochemistry of Marine Dissolved Organic Matter, edited by: Hansell, D. A. and Carlson, C. A., Academic Press, San Diego, CA, 5990, 2002.

Bigg, E. K. and Leck, C.: The composition of fragments of bubbles bursting at the ocean surface, J. Geophys. Res., 113, D11209, doi:10.1029/2007JD009078, 2008.

Blanchard, D. C.: Sea-to-air transport surface active material, Science, 146, 396-397, 1964.

Blanchard, D. C. and Woodcock, A. H.: Bubble formation and modification in the sea and its meteorological significance, Tellus, 9, 145-158, 1957.

Ciais, P., Sabine, C., Bala, G., Bopp, L., Brovkin, V., Canadell, J. G., Chhabra, A., DeFries, R., Galloway, J., Heimann, M., Jones, C., Le Quéré, C., Myneni, R. B., Piao, S., and Thornton, P.: Carbon and Other Biogeochemical Cycles, in: Climate Change 2013: The Physical Science Basis. Contribution of Working Group I to the Fifth Assessment Report of the Intergovernmental Panel on Climate Change, edited by: Stocker, B. D., Qin, D., Plattner, G.-K., Tignor, M., Allen, S. K., Boschung, J., Nauels, A., Xia, Y., Bex, V., and Midgley, P. M., Cambridge, United Kingdom and New York, NY, USA, Cambridge University Press, 465-570, 2013.

Callaghan, A. H., Deane, G. B., Stokes, M. D., and Ward, B.: Observed variation in the decay time of oceanic whitecap foam, J. Geophys. Res., 117, C09015, doi:10.1029/2012JC008147, 2012.

Cameron-Smith, P., Elliott, S., Maltrud, M., Erickson, D., and Wingenter, O.: Changes in dimethyl sulfide oceanic distribution due to climate change, Geophys. Res. Lett., 38, L07704, doi:10.1029/2011GL047069, 2011. 
Clarke, A. D., Owens, S. R., and Zhou, J.: An ultrafine sea-salt flux from breaking waves: implications for cloud condensation nuclei in the remote marine atmosphere, J. Geophys. Res., 111, D06202, doi:10.1029/2005JD006565, 2006.

Collins, D. B., Ault, A. P., Moffet, R. C., Ruppel, M. J., CuadraRodriguez, L. A., Guasco, T. L., Corrigan, C. E., Pedler, B. E., Azam, F., Aluwihare, L. I., Bertram, T. H., Roberts, G. C., Grassian, V. H., and Prather, K. A.: Impact of marine biogeochemistry on the chemical mixing state and cloud forming ability of nascent sea spray aerosol, J. Geophys. Res.-Atmos., 118, 85538565, 2013.

Cunliffe, M., Engel, A., Frka, S., Gašparović, B., Guitart, C., Murrell, J. C., Salter, M., Stolle, C., Upstill-Goddard, R., and Wurl, O.: Sea surface microlayers: A unified physicochemical and biological perspective of the air-ocean interface, Prog. Oceanogr., 109, 104-116, 2013.

Doney, S. C., Ruckelshaus, M., Duffy, J. E., Barry, J. P., Chan, F., English, C. A., Galindo, H. M., Grebmeier, J. M., Hollowed, A. B., Knowlton, N., Polovina, J., Rabalais, N. N., Sydeman, W. J., and Talley, L. D.: Climate Change Impacts on Marine Ecosystems, Annual Review of Marine Science, 4, 11-37, doi:10.1146/annurev-marine-041911-111611, 2012.

D'Ortenzio, F. and Ribera d'Alcalà, M.: On the trophic regimes of the Mediterranean Sea: a satellite analysis, Biogeosciences, 6, 139-148, doi:10.5194/bg-6-139-2009, 2009.

Ducklow, H. W., Carlson, C. A., Bates, N. R., Knap, A. H., Michaels, A. F., Jickells, T., Le, P. J., Williams, B., and McCave, I. N.: Dissolved Organic Carbon as a Component of the Biological Pump in the North Atlantic Ocean, Philos. T. Roy. Soc. B, 348, 161-167, 1995.

Engel, A.: Determination of marine gel particles, in: Practical Guidelines for the Analysis of Seawater, edited by: Wurl, O., CRC Press, Boca Raton, Florida, 125-142, 2009.

Facchini, M. C., Rinaldi, M., Decesari, S., Carbone, C., Finessi, E., Mircea, M., Fuzzi, S., Ceburnis, D., Flanagan, R., Nilsson, E. D., de Leeuw, G., Martino, M., Woeltjen, J., and O'Dowd, C. D.: Primary submicron marine aerosol dominated by insoluble organic colloids and aggregates, Geophys. Res. Lett., 35, L17814, doi:10.1029/2008GL034210, 2008.

Filella, M.: Understanding what we are measuring: standards and quantification of natural organic matter, Water Res., 50, 287-293, 2014.

Fuentes, E., Coe, H., Green, D., de Leeuw, G., and McFiggans, G.: Laboratory-generated primary marine aerosol via bubblebursting and atomization, Atmos. Meas. Tech., 3, 141-162, doi:10.5194/amt-3-141-2010, 2010a.

Fuentes, E., Coe, H., Green, D., de Leeuw, G., and McFiggans, G.: On the impacts of phytoplankton-derived organic matter on the properties of the primary marine aerosol - Part 1: Source fluxes, Atmos. Chem. Phys., 10, 9295-9317, doi:10.5194/acp-10-92952010, 2010b.

Fuentes, E., Coe, H., Green, D., and McFiggans, G.: On the impacts of phytoplankton-derived organic matter on the properties of the primary marine aerosol - Part 2: Composition, hygroscopicity and cloud condensation activity, Atmos. Chem. Phys., 11, 25852602, doi:10.5194/acp-11-2585-2011, 2011.

Galgani, L., Stolle, C., Endres, S., Schulz, K. G., and Engel, A.: Effects of ocean acidification on the biogenic composition of the sea-surface microlayer: Results from a mesocosm study, J. Geophys. Res.-Oceans, 119, 7911-7924, doi:10.1002/2014JC010188, 2014.

Gantt, B. and Meskhidze, N.: The physical and chemical characteristics of marine primary organic aerosol: a review, Atmos. Chem. Phys., 13, 3979-3996, doi:10.5194/acp-13-3979-2013, 2013.

Gantt, B., Meskhidze, N., Facchini, M. C., Rinaldi, M., Ceburnis, D., and O'Dowd, C. D.: Wind speed dependent size-resolved parameterization for the organic mass fraction of sea spray aerosol, Atmos. Chem. Phys., 11, 8777-8790, doi:10.5194/acp-11-87772011, 2011.

Garrett, W. D.: The organic chemical composition of the ocean surface, Deep-Sea Res., 14 , 221-227, 1967.

Gazeau, F., Ziveri, P., Sallon, A., Lejeune, P., Gobert, S., Maugendre, L., Louis, J., Alliouane, S., Taillandier, V., Louis, F., Obolensky, G., Grisoni, J.-M., Delissanti, W., Luquet, D., Robin, D., Hesse, B., and Guieu, C.: First mesocosm experiments to study the impacts of ocean acidification on the plankton communities in the NW Mediterranean Sea (MedSeA project), submitted, 2015.

Gruber, D. F., Simjouw, J.-P., Seitzinger, S. P., and Taghon, G. L.: Dynamics and characterization of refractory dissolved organic matter produced by a pure bacterial culture in an experimental predator-prey system, Appl. Environ. Microb., 72, 4184-4191, 2006.

Grythe, H., Ström, J., Krejci, R., Quinn, P., and Stohl, A.: A review of sea-spray aerosol source functions using a large global set of sea salt aerosol concentration measurements, Atmos. Chem. Phys., 14, 1277-1297, doi:10.5194/acp-14-1277-2014, 2014.

Guieu, C., Dulac, F., Ridame, C., and Pondaven, P.: Introduction to project DUNE, a DUst experiment in a low Nutrient, low chlorophyll Ecosystem, Biogeosciences, 11, 425-442, doi:10.5194/bg11-425-2014, 2014.

Hansell, D. A., Carlson, C. A., Repeta, D. J., and Schlitzer, R.: Dissolved organic matter in the ocean, Oceanography, 22, 202-211, 2009.

Hare, C. E., Leblanc, K., DiTullio, G. R., Kudela, R. M., Zhang, Y., Lee, P. A., Riseman, S., and Hutchins, D. A.: Consequences of increased temperature and $\mathrm{CO}_{2}$ for phytoplankton community structure in the Bering Sea, Mar. Ecol.-Prog. Ser., 352, 9-16, 2007.

Hegg, D. A., Covert, D. S., Jonsson, H. H., and Woods, R.: Differentiating natural and anthropogenic cloud condensation nuclei in the California coastal zone, Tellus B, 61, 669-676, doi:10.1111/j.1600-0889.2009.00435.x, 2009.

Hultin, K., Nilsson, E. D., Krejci, R., Mårtensson, E. M., Ehn, M., Hagström, ̊., and de Leeuw, G.: In situ laboratory sea spray production during the Marine Aerosol Production 2006 cruise on the northeastern Atlantic Ocean, J. Geophys. Res., 115, D06201, doi:10.1029/2009JD012522, 2010.

Hultin, K., Krejci, R., Pinhassi, J., Gomez-Consarnau, L., Mårtensson, E. M., Hagström, A., and Nilsson, E. D.: Aerosol and bacterial emissions from Baltic Seawater, Atmos. Res., 99 , 1-14, 2011.

IPCC: Climate Change 2013: The Physical Science Basis, in: Contribution of Working Group I to the Fifth Assessment Report of the Intergovernmental Panel on Climate Change, edited by: Stocker, T. F., Qin, D., Plattner, G.-K., Tignor, M., Allen, S. K., Boschung, J., Nauels, A., Xia, Y., Bex, V., and Midgley, P. M., 
Cambridge, United Kingdom and New York, NY, USA, Cambridge University Press, 2013.

Irwin, A. J. and Oliver, M. J.: Are ocean deserts getting larger?, Geophys. Res. Lett., 36, L18609, doi:10.1029/2009GL039883, 2009.

Jiao, N., Herndl, G. J., Hansell, D. A., Benner, R., Kattner, G., Wilhelm, S. W., Kirchman, D. L., Weinbauer, M. G., Luo, T., Chen, F., and Azam, F.: Microbial production of recalcitrant dissolved organic matter: long-term carbon storage in the global ocean, Nat. Rev. Microbiol., 8, 593-599, 2010.

Keene, W. C., Maring, H., Maben, J. R., Kieber, D. J., Pszenny, A. A. P., Dahl, E. E., Izaguirre, M. A., Davis, A. J., Long, M. S., Zhou, X., Smoydzin, L., and Sander, R.: Chemical and physical characteristics of nascent aerosols produced by bursting bubbles at a model air-sea interface, J. Geophys. Res., 112, D21202, doi:10.1029/2007JD008464, 2007.

King, S. M., Butcher, A. C., Rosenoern, T., Coz, E., Lieke, K. I., de Leeuw, G., Nilsson, E. D., and Bilde, M.: Investigating primary marine aerosol properties: $\mathrm{CCN}$ activity of sea salt and mixed inorganic-organic particles, Environ. Sci. Technol., 46, 1040510412, 2012.

Langmann, B., Scannell, C., and O'Dowd, C.: New directions: organic matter contribution to marine aerosols and cloud condensation nuclei, Atmos. Environ., 42, 7821-7822, 2008.

Le Quéré, C., Moriarty, R., Andrew, R. M., Peters, G.'P., Ciais, P., Friedlingstein, P., Jones, S. D., Sitch, S., Tans, P., Arneth, A., Boden, T. A., Bopp, L., Bozec, Y., Canadell, J. G., Chini, L. P., Chevallier, F., Cosca, C. E., Harris, I., Hoppema, M., Houghton, R. A., House, J. I., Jain, A. K., Johannessen, T., Kato, E., Keeling, R. F., Kitidis, V., Klein Goldewijk, K., Koven, C., Landa, C. S., Landschützer, P., Lenton, A., Lima, I. D., Marland, G., Mathis, J. T., Metzl, N., Nojiri, Y., Olsen, A., Ono, T., Peng, S., Peters, W., Pfeil, B., Poulter, B., Raupach, M. R., Regnier, P., Rödenbeck, C., Saito, S., Salisbury, J. E., Schuster, U., Schwinger, J., Séférian, R., Segschneider, J., Steinhoff, T., Stocker, B. D., Sutton, A. J., Takahashi, T., Tilbrook, B., van der Werf, G. R., Viovy, N., Wang, Y.-P., Wanninkhof, R., Wiltshire, A., and Zeng, N.: Global carbon budget 2014, Earth Syst. Sci. Data, 7, 47-85, doi:10.5194/essd-7-47-2015, 2015.

Lewis, S. and Schwartz, R.: Sea Salt Aerosol Production: Mechanisms, Methods, Measurements, and Models - A Critical Review, American Geophysical Union, Washington, DC, 1-413, 2004.

Lion, L. W. and Leckie, J. O.: The biogeochemistry of the air-sea interface, Annu. Rev. Earth Pl. Sc., 9, 449-486, 1981.

Long, M. S., Keene, W. C., Kieber, D. J., Erickson, D. J., and Maring, H.: A sea-state based source function for size- and composition-resolved marine aerosol production, Atmos. Chem. Phys., 11, 1203-1216, doi:10.5194/acp-11-1203-2011, 2011.

Mårtensson, E. M., Nilsson, E. D., de Leeuw, G., Cohen, L. H., and Hansson, H.-C.: Laboratory simulations and parameterization of the primary marine aerosol production, J. Geophys. Res., 108, 4297, doi:10.1029/2002JD002263, 2003.

The MerMex Group: Marine ecosystems responses to climatic and anthropogenic forcings in the Mediterranean, Prog. Oceanogr., 91, 97-166, 2011.

Matrai, P. A., Tranvik, L., Leck, C., and Knulst, J. C.: Are high Arctic surface microlayers a potential source of aerosol organic precursors?, Mar. Chem., 108, 109-122, 2008.
Moore, M. J. K., Furutani, H., Roberts, G. C., Moffet, R. C., Gilles, M. K., Palenik, B., and Prather, K. A.: Effect of organic compounds on cloud condensation nuclei $(\mathrm{CCN})$ activity of sea spray aerosol produced by bubble bursting, Atmos. Environ., 45, 7462 7469, 2011.

Moutin, T. and Raimbault, P.: Primary production, carbon export and nutrients availability in western and eastern Mediterranean Sea in early summer 1996 (MINOS cruise), J. Marine Syst., 3334, 273-288, 2002.

Murphy, D. M., Anderson, J. R., Quinn, P. K., McInnes, L. M., Brechtel, F. J., Kreidenweis, S. M., Middlebrook, A. M., Pósfai, M., Thomson, D. S., and Buseck, P. R.: Influence of sea-salt on aerosol radiative properties in the Southern Ocean marine boundary layer, Nature, 392, 62-65, 1998.

Novakov, T. and Corrigan, C. E.: Cloud condensation nucleus activity of the organic component of biomass smoke particles, Geophys. Res. Lett., 23, 2141-2144, doi:10.1029/96GL01971, 1996.

Novakov, T. and Penner, J. E.: Large contribution of organic aerosols to cloud-condensation-nuclei concentrations, Nature, 365, 823-826, doi:10.1038/365823a0, 1993.

O’Dowd, C. D., Facchini, M. C., Cavalli, F., Ceburnis, D., Mircea, M., Decesari, S., Fuzzi, S., Yoon, Y. J., and Putaud, J.-P.: Biogenically driven organic contribution to marine aerosol, Nature, 431, 676-680, 2004.

O’Dowd, C. D., Langmann, B., Varghese, S., Scannell, C., Ceburnis, D., and Facchini, M. C.: A combined organic-inorganic sea-spray source function, Geophys. Res. Lett., 35, L01801, doi:10.1029/2007GL030331, 2008.

Ogawa, H., Amagai, Y., Koike, I., Kaiser, K., and Benner, R.: Production of refractory dissolved organic matter by bacteria, Science, 292, 917-920, 2001.

Passow, U.: The abiotic formation of TEP under different ocean acidification scenarios, Mar. Chem., 128-129, 72-80, 2012.

Petters, M. D. and Kreidenweis, S. M.: A single parameter representation of hygroscopic growth and cloud condensation nucleus activity, Atmos. Chem. Phys., 7, 1961-1971, doi:10.5194/acp-71961-2007, 2007.

Polovina, J. J., Howell, E. A., and Abecassis, M.: Ocean's least productive waters are expanding, Geophys. Res. Lett., 35, L03618, doi:10.1029/2007GL031745, 2008.

Prather, K. A., Bertram, T. H., Grassian, V. H., Deane, G. B., Stokes, M. D., Demott, P. J., Aluwihare, L. I., Palenik, B. P., Azam, F., Seinfeld, J. H., Moffet, R. C., Molina, M. J., Cappa, C. D., Geiger, F. M., Roberts, G. C., Russell, L. M., Ault, A. P., Baltrusaitis, J., Collins, D. B., Corrigan, C. E., Cuadra-Rodriguez, L. A., Ebben, C. J., Forestieri, S. D., Guasco, T. L., Hersey, S. P., Kim, M. J., Lambert, W. F., Modini, R. L., Mui, W., Pedler, B. E., Ruppel, M. J., Ryder, O. S., Schoepp, N. G., Sullivan, R. C., and Zhao, D.: Bringing the ocean into the laboratory to probe the chemical complexity of sea spray aerosol, P. Natl. Acad. Sci. USA, 110, 7550-7555, 2013.

Pringle, K. J., Tost, H., Pozzer, A., Pöschl, U., and Lelieveld, J.: Global distribution of the effective aerosol hygroscopicity parameter for $\mathrm{CCN}$ activation, Atmos. Chem. Phys., 10, 52415255, doi:10.5194/acp-10-5241-2010, 2010.

Quinn, P. K. and Bates, T. S.: The case against climate regulation via oceanic phytoplankton sulphur emissions, Nature, 480, 51$56,2011$. 
Riebesell, U. and Tortell, P. D.: Effects of ocean acidification on pelagic organisms and ecosystems, in: Ocean Acidification, edited by: Gattuso, J. P. and Hansson, L., Oxford University Press, Oxford, 99-121, 2011.

Riebesell, U., Bellerby, R. G. J., Grossart, H.-P., and Thingstad, F.: Mesocosm $\mathrm{CO}_{2}$ perturbation studies: from organism to community level, Biogeosciences, 5, 1157-1164, doi:10.5194/bg-51157-2008, 2008.

Riebesell, U., Czerny, J., von Bröckel, K., Boxhammer, T., Büdenbender, J., Deckelnick, M., Fischer, M., Hoffmann, D., Krug, S. A., Lentz, U., Ludwig, A., Muche, R., and Schulz, K. G.: Technical Note: A mobile sea-going mesocosm system - new opportunities for ocean change research, Biogeosciences, 10, 18351847, doi:10.5194/bg-10-1835-2013, 2013.

Rinaldi, M., Fuzzi, S., Decesari, S., Marullo, S., Santoleri, R., Provenzale, A., von Hardenberg, J., Ceburnis, D., Vaishya, A., O'Dowd, C. D., and Facchini, M. C.: Is chlorophyll $a$ the best surrogate for organic matter enrichment in submicron primary marine aerosol?, J. Geophys. Res.-Atmos., 118, 4964-4973, 2013.

Roberts, G. C. and Nenes, A.: A continuous-flow streamwise thermal-gradient $\mathrm{CCN}$ chamber for atmospheric measurements, Aerosol Sci. Tech., 39, 206-221, 2005.

Russell, L. M., Hawkins, L. N., Frossard, A., Quinn, P. K., and Bates, T. S.: Carbohydrate-like composition of submicron atmospheric particles and their production from ocean bubble bursting, P. Natl. Acad. Sci. USA, 107, 6652-6657, 2010.

Schulz, K. G., Bellerby, R. G. J., Brussaard, C. P. D., Büdenbender, J., Czerny, J., Engel, A., Fischer, M., Koch-Klavsen, S., Krug, S. A., Lischka, S., Ludwig, A., Meyerhöfer, M., Nondal, G., Silyakova, A., Stuhr, A., and Riebesell, U.: Temporal biomass dynamics of an Arctic plankton bloom in response to increasing levels of atmospheric carbon dioxide, Biogeosciences, 10, 161180, doi:10.5194/bg-10-161-2013, 2013.

Sciare, J., Mihalopoulos, N., and Dentener, F. J.: Interannual variability of atmospheric dimethylsulfide in the southern Indian Ocean, J. Geophys. Res., 105, 26369-26377, 2000.

Sciare, J., Favez, O., Sarda-Estève, R., Oikonomou, K., Cachier, H., and Kazan, V.: Long-term observations of carbonaceous aerosols in the Austral Ocean atmosphere: evidence of a biogenic marine organic source, J. Geophys. Res., 114, D15302, doi:10.1029/2009JD011998, 2009.

Sellegri, K., O’Dowd, C. D., Yoon, Y. J., Jennings, S. G., and de Leeuw, G.: Surfactants and submicron sea spray generation, J. Geophys. Res., 111, D22215, doi:10.1029/2005JD006658, 2006.

Siokou-Frangou, I., Christaki, U., Mazzocchi, M. G., Montresor, M., Ribera d'Alcalá, M., Vaqué, D., and Zingone, A.: Plankton in the open Mediterranean Sea: a review, Biogeosciences, 7, 15431586, doi:10.5194/bg-7-1543-2010, 2010.
Spracklen, D. V., Arnold, S. R., Sciare, J., Carslaw, K. S., and Pio, C.: Globally significant oceanic source of organic carbon aerosol, Geophys. Res. Lett., 35, L12811, doi:10.1029/2008GL033359, 2008.

Stewart, R. I. A., Dossena, M., Bohan, D. A., Jeppesen, E., Kordas, R. L., Ledger, M. E., Meerhoff, M., Moss, B., Mulder, C., Shurin, J. B., Suttle, B., Thompson, R., Trimmer, M., and Woodward, G.: Mesocosm Experiments as a Tool for Ecological ClimateChange Research, in: Global Change in Multispecies Systems, Part 3., edited by: Woodward, G. and O'Gorman, E. J., Advances in Ecological research, Elsevier, 71-181, 2013.

Stommel, Y. G. and Riebel, U.: A new corona discharge-based aerosol charger for submicron particles with low initial charge, J. Aerosol Sci., 35, 1051-1069, 2004.

Stommel, Y. G. and Riebel, U.: A corona-discharge-based aerosol neutralizer designed for use with the SMPS-system, J. Electrostat., 63, 917-921, 2005.

Tyree, C. A., Hellion, V. M., Alexandrova, O. A., and Allen, J. O.: Foam droplets generated from natural and artificial seawaters, J. Geophys. Res., 112, D12204, doi:10.1029/2006JD007729, 2007.

Vignati, E., Facchini, M. C., Rinaldi, M., Scannell, C., Ceburnis, D., Sciare, J., Kanakidou, M., Myriokefalitakis, S., Dentener, F., and O'Dowd, C. D.: Global scale emission and distribution of seaspray aerosol: sea-salt and organic enrichment, Atmos. Environ., 44, 670-677, 2010.

Weinbauer, M. G., Mari, X., and Gattuso, J.-P.: Effect of ocean acidification on the diversity and activity of heterotrophic marine microorganisms, in: Ocean Acidification, edited by: Gattuso, J.-P. and Hansson, L., Oxford University Press, Oxford, 83-98, 2011.

Woodhouse, M. T., Mann, G. W., Carslaw, K. S., and Boucher, O.: Sensitivity of cloud condensation nuclei to regional changes in dimethyl-sulphide emissions, Atmos. Chem. Phys., 13, 27232733, doi:10.5194/acp-13-2723-2013, 2013.

Yoon, Y. J., Ceburnis, D., Cavalli, F., Jourdan, O., Putaud, J. P., Facchini, M. C., Decesari, S., Fuzzi, S., Sellegri, K., Jennings, S. G., and O'Dowd, C. D.: Seasonal characteristics of the physicochemical properties of North Atlantic marine atmospheric aerosols, J. Geophys. Res., 112, D04206, doi:10.1029/2005JD007044, 2007.

Zábori, J., Krejci, R., Ekman, A. M. L., Mårtensson, E. M., Ström, J., de Leeuw, G., and Nilsson, E. D.: Wintertime Arctic Ocean sea water properties and primary marine aerosol concentrations, Atmos. Chem. Phys., 12, 10405-10421, doi:10.5194/acp-1210405-2012, 2012a.

Zábori, J., Matisāns, M., Krejci, R., Nilsson, E. D., and Ström, J.: Artificial primary marine aerosol production: a laboratory study with varying water temperature, salinity, and succinic acid concentration, Atmos. Chem. Phys., 12, 10709-10724, doi:10.5194/acp-12-10709-2012, 2012b. 